Keywords: $D W P F$

SRAT

reductant

Retention: Permanent

\title{
Glycolic-Formic Acid Flowsheet Sludge Matrix Study
}

\author{
D.P. Lambert \\ D.C. Koopman
}

June 30, 2011

Savannah River National Laboratory Savannah River Nuclear Solutions, LLC Aiken, SC 29808

Prepared for the U.S. Department of Energy under contract number DE-AC09-08SR22470.

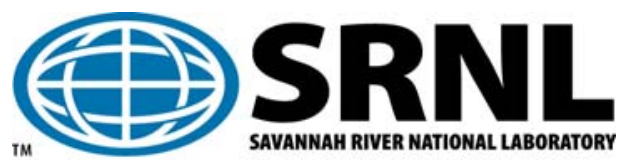


SRNL-STI-2011-00275

Revision 0

\section{DISCLAIMER}

This work was prepared under an agreement with and funded by the U.S. Government. Neither the U.S. Government or its employees, nor any of its contractors, subcontractors or their employees, makes any express or implied:

1. warranty or assumes any legal liability for the accuracy, completeness, or for the use or results of such use of any information, product, or process disclosed; or

2. representation that such use or results of such use would not infringe privately owned rights; or

3. endorsement or recommendation of any specifically identified commercial product, process, or service.

Any views and opinions of authors expressed in this work do not necessarily state or reflect those of the United States Government, or its contractors, or subcontractors.

\section{Printed in the United States of America \\ Prepared for \\ U.S. Department of Energy}




\section{REVIEWS AND APPROVALS}

AUTHORS:

D.P. Lambert, ERPS/Process Technology Programs Date

D.C. Koopman, ERPS/Process Technology Programs Date

TECHNICAL REVIEW:

M.E. Stone, ERPS/Process Technology Programs Date APPROVAL:

C.C. Herman, Manager Date ERPS/Process Technology Programs

S.L. Marra, Manager Date

Environmental \& Chemical Process Technology Research Programs

J.E. Occhipinti, Manager Date

Waste Solidification Engineering 
SRNL-STI-2011-00275

Revision 0

\section{EXECUTIVE SUMMARY}

Testing was completed to demonstrate the viability of the newly developed glycolic acid/formic acid flowsheet on processing in the Defense Waste Processing Facility's (DWPF) Chemical Process Cell (CPC). The Savannah River National Laboratory (SRNL) initiated a sludge matrix study to evaluate the impact of changing insoluble solid composition on the processing characteristics of slurries in DWPF. Four sludge simulants were prepared to cover two compositional ranges in the waste. The first was high iron/low aluminum versus low iron/high aluminum (referred to as $\mathrm{HiFe}$ or LoFe in this report). The second was high calciummanganese/low nickel, chromium, and magnesium versus low calcium-manganese/high nickel, chromium, and magnesium (referred to as HiMn or LoMn in this report). These two options can be combined to form four distinct sludge compositions.

The sludge matrix study called for testing each of these four simulants near the minimum acid required for nitrite destruction (100\% acid stoichiometry) and at a second acid level that produced significant hydrogen by noble metal catalyzed decomposition of formic acid $(150 \%$ acid stoichiometry). Four simulants were prepared based on the four possible combinations of the $\mathrm{Al} / \mathrm{Fe}$ and $\mathrm{Mn}-\mathrm{Ca} / \mathrm{Mg}-\mathrm{Ni}-\mathrm{Cr}$ options. Preliminary simulant preparation work has already been documented. ${ }^{1}$ The four simulants were used for high and low acid testing.

Eight planned experiments (GF26 to GF33) were completed to demonstrate the viability of the glycolic-formic flowsheet. Composition and physical property measurements were made on the SRAT product. Composition measurements were made on the condensate from the Mercury Water Wash Tank (MWWT), Formic Acid Vent Condenser (FAVC), ammonia scrubber and on SRAT samples pulled throughout the SRAT cycle. Updated values for formate loss and nitrite-tonitrate conversion were found that can be used in the acid calculations for future sludge matrix process simulations with the glycolic acid/formic acid flowsheet.

Preliminary results of the initial testing indicate:

- Hydrogen generation rate was very low throughout all SRAT cycles.

- The mercury concentration of the SRAT product was below the $0.8 \mathrm{wt} \%$ limit in all runs.

- Nitrite in the SRAT product was $<100 \mathrm{mg} / \mathrm{kg}$ for all runs

- Foaminess was not an issue using the nominal antifoam addition strategy in these tests.

- The high aluminum sludges (LoFe, HM type sludges) were much more viscous than the $\mathrm{Hi} \mathrm{Fe}$ sludges. At 100\% acid stoichiometry, the SRAT products from the high aluminum sludges were very viscous but at $150 \%$ acid stoichiometry, the SRAT products from the high aluminum sludges were very thin. This makes the glycolic acid/formic acid flowsheet an improvement for processing more viscous sludges.

- The $\mathrm{pH}$ of the SRAT products was from 2.7-3.1 for the $150 \%$ acid stoichiometry runs and 5.1-6.1 for the $100 \%$ acid stoichiometry runs, significantly lower than is typical of the baseline nitric acid/formic acid flowsheet. 


\section{TABLE OF CONTENTS}

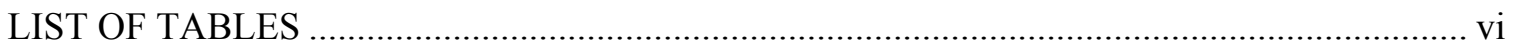

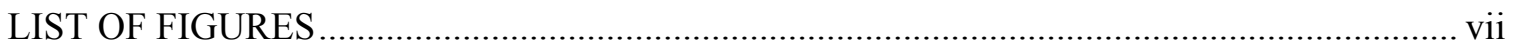

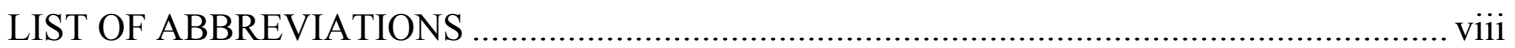

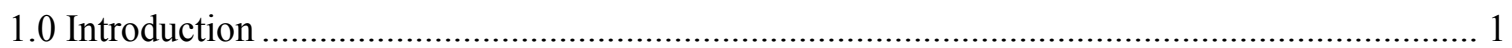

1.1 Demonstration of Glycolic-Formic Flowsheet Over Wide Sludge Composition Range ....... 1

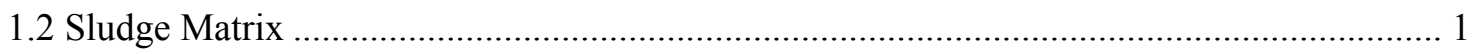

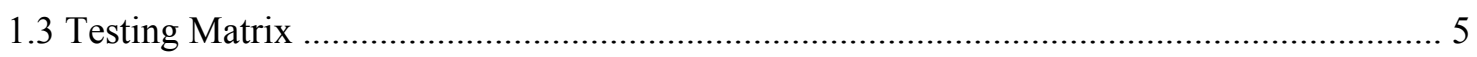

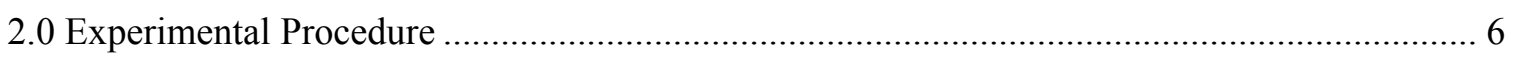

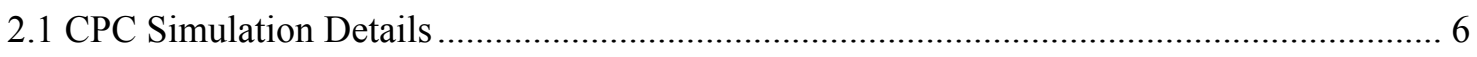

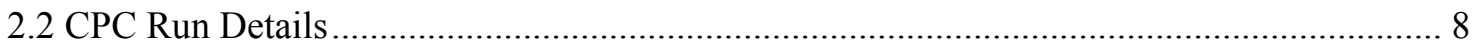

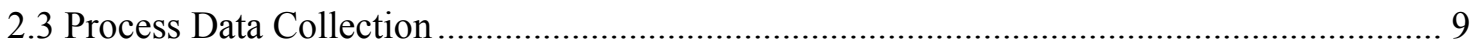

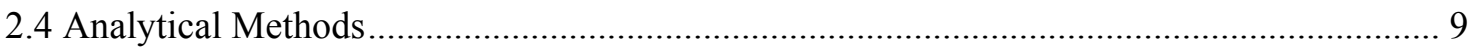

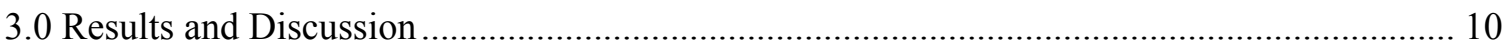

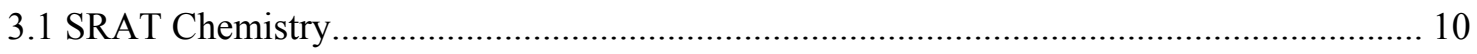

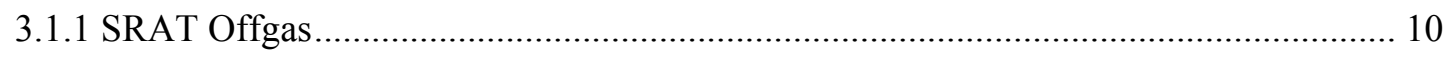

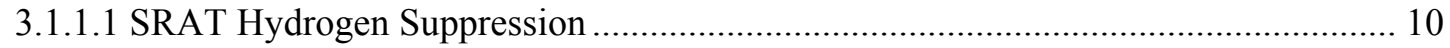

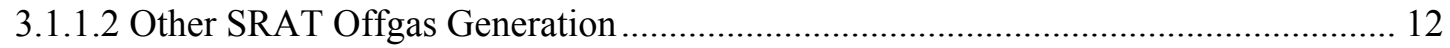

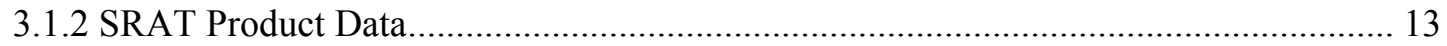

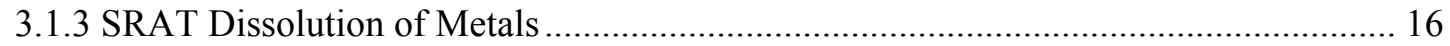

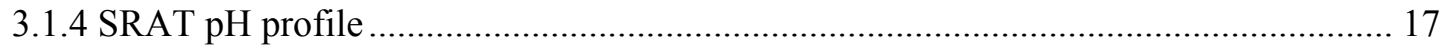

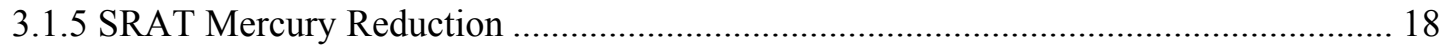

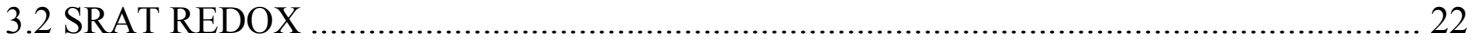

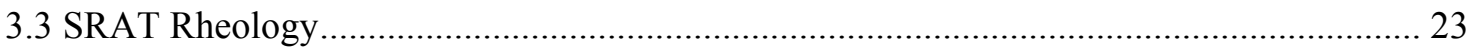

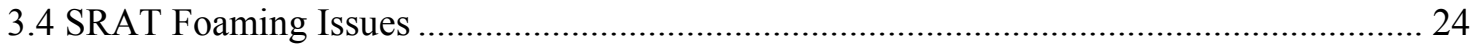

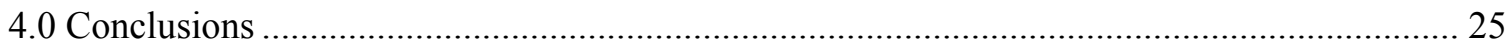

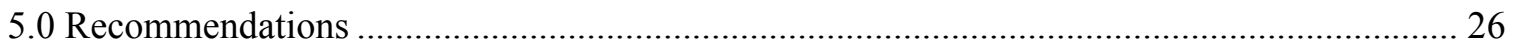

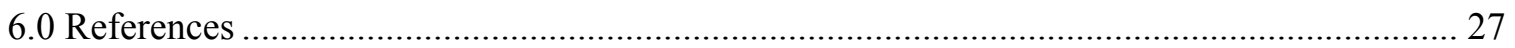

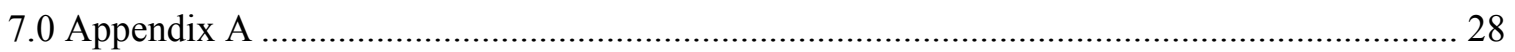




\section{LIST OF TABLES}

Table 1-1. Elemental Composition of Simulants Calcined at $1,100^{\circ} \mathrm{C}, \mathrm{wt} \%$.............................. 4

Table 1-2. Mercury and Noble Metal Composition of Simulants Dried at $110^{\circ} \mathrm{C}$, wt $\%$.............. 5

Table 1-3. Acid Stoichiometry of Matrix Sludge Runs .............................................................. 5

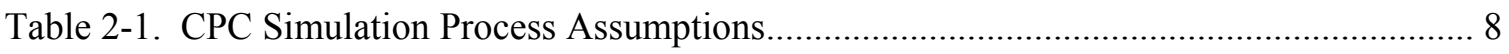

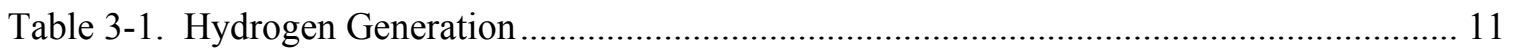

Table 3-2. SRAT Product Anions, Solids, Density, and pH Data ............................................... 14

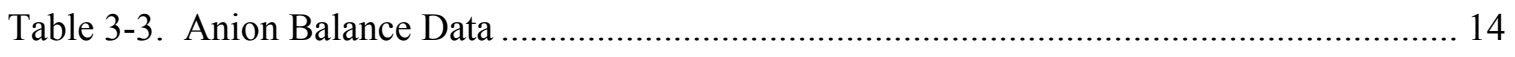

Table 3-4. SRAT Product Elemental Data, wt \% calcined solids basis ....................................... 15

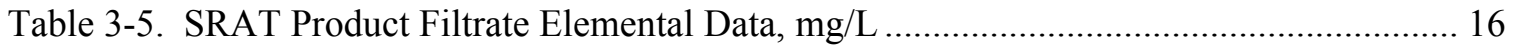

Table 3-6. SRAT Product Supernate \% of Element Dissolved .................................................. 17

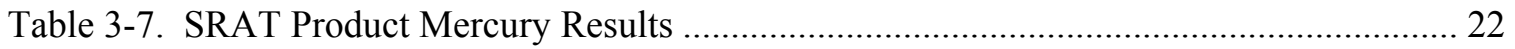

Table 3-8. SRAT product data for REDOX calculations ......................................................... 23

Table 3-9. SRAT product Bingham plastic model results........................................................ 24 


\section{LIST OF FIGURES}

Figure 1-1. Definition of Sludge Matrix Simulants.................................................................... 2

Figure 1-2. A1, Fe concentration in Sludge Batches SB3 to SB6 compared to Matrix Simulants .. 3

Figure 1-3. Al, Ni concentration in Sludge Batches SB3 to SB6 compared to Matrix Simulants .. 3

Figure 1-4. Al, Mn concentration in Sludge Batches SB3 to SB6 compared to Matrix Simulants. 4

Figure 2-1. Schematic of SRAT Equipment Set-Up ............................................................. 7

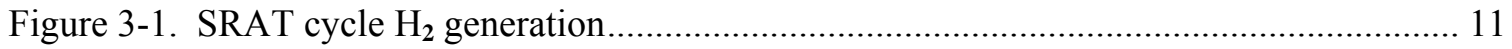

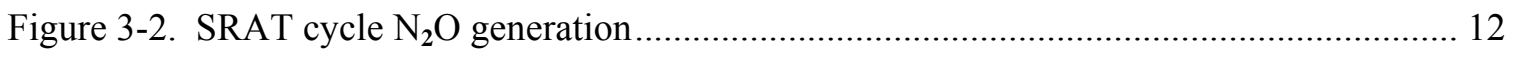

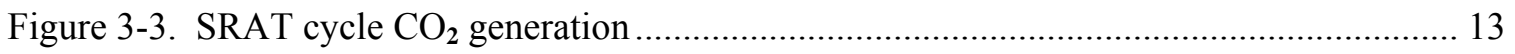

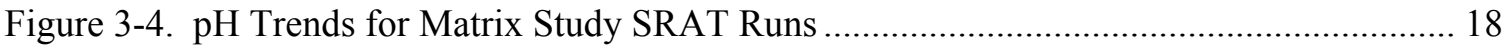

Figure 3-5. Mercury concentration with time in all SRAT cycles ........................................... 19

Figure 3-6. Mercury concentration with time in GF26 and GF27 SRAT cycles......................... 20

Figure 3-7. Mercury concentration with time in GF28 and GF29 SRAT cycles......................... 20

Figure 3-8. Mercury concentration with time in GF30 and GF31 SRAT cycles........................ 21

Figure 3-9. Mercury concentration with time in GF32, GF32A, GF33 and GF33A SRAT cycles 21 


\section{LIST OF ABBREVIATIONS}

$\begin{array}{ll}\text { AD } & \text { Analytical Development } \\ \text { ARP } & \text { Actinide Removal Process } \\ \text { CPC } & \text { Chemical Process Cell } \\ \text { GC } & \text { Gas Chromatograph } \\ \text { FAVC } & \text { Formic Acid Vent Condenser } \\ \text { IC } & \text { Ion Chromatography } \\ \text { ICP-AES } & \text { Inductively Coupled Plasma-Atomic Emission Spectroscopy } \\ \text { MCU } & \text { Modular Caustic Side Solvent Extraction Unit } \\ \text { MWWT } & \text { Mercury Water Wash Tank } \\ \text { PSAL } & \text { Process Science Analytical Laboratory } \\ \text { REDOX } & \text { Reduction/Oxidation } \\ \text { SME } & \text { Slurry Mix Evaporator } \\ \text { SMECT } & \text { Slurry Mix Evaporator Condensate Tank } \\ \text { SRAT } & \text { Sludge Receipt and Adjustment Tank } \\ \text { SRNL } & \text { Savannah River National Laboratory } \\ \text { SRR } & \text { Savannah River Remediation } \\ \text { SVOA } & \text { Semi-Volatile Organics Analysis } \\ \text { TIC } & \text { Total Inorganic Carbon Analysis } \\ \text { TOC } & \text { Total Organic Carbon Analysis } \\ \text { TT\&QAP } & \text { Task Technical and Quality Assurance Plan } \\ \text { TTR } & \text { Technical Task Request } \\ \text { VOA } & \text { Volatile/semi-volatile Organics Analysis } \\ \text { VSL } & \text { Vitreous State Laboratory } \\ & \end{array}$




\subsection{Introduction}

Savannah River Remediation (SRR) is evaluating changes to its current Defense Waste Processing Facility (DWPF) flowsheet to improve processing cycle times that will enable the facility to support higher canister production while maximizing waste loading after installation of the bubblers into the melter. Due to the significant maintenance required for the DWPF Gas Chromatographs (GC) and the potential for production of flammable quantities of hydrogen, reducing the amount of formic acid used in the Chemical Process Cell (CPC) is one of the options being considered. Earlier work at Savannah River National Laboratory has shown that replacing formic acid in the existing nitric/formic acid flowsheet with an 80:20 molar blend of glycolic and formic acids has the potential to remove mercury in the SRAT without any significant catalytic hydrogen generation.

A number of studies ${ }^{2,3,4,5}$ have been completed to demonstrate the effectiveness of this flowsheet. These previous studies were all completed with the SB6H simulant produced for SRNL by Harrell Industries. The current study is designed to demonstrate the effectiveness of the glycolicformic flowsheet with a much wider compositional sludge matrix using the sludge matrix produced sludge simulants ${ }^{6}$.

\subsection{Demonstration of Glycolic-Formic Flowsheet Over Wide Sludge Composition Range}

The objective of the testing detailed in this document is to determine the viability of the glycolicformic acid flowsheet in processing sludge over a wide compositional range as requested by DWPF. This work was performed under the guidance of a Task Technical and Quality Assurance Plan (TT\&QAP). ${ }^{7}$

\subsection{Sludge Matrix}

SRNL produced four matrix sludge simulants in order to improve the understanding of how changing sludge composition impacts DWPF waste processing. These simulants have been used in other SRNL studies and the composition has been previously measured.

There are many elements in the insoluble solids. The two major insoluble elements in SRS high activity waste slurries are iron and aluminum, corresponding to Purex and HM wastes respectively. The first solids concentration parameter was chosen to reflect variations between these two elements. There are a number of elements that occur at about an order of magnitude lower concentration than $\mathrm{Al}$ and $\mathrm{Fe}$ in SRS waste slurries including $\mathrm{Ca}, \mathrm{Hg}, \mathrm{Mg}, \mathrm{Mn}, \mathrm{Ni}$, and $\mathrm{Si}$ (also U, but that is outside the scope of this study). These can be defined as the semi-major elements. Creating high-low pairs from all of these elements in addition to $\mathrm{Al}$ and $\mathrm{Fe}$ would have led to a prohibitively large study. The size of the study was controlled by grouping some of the semi-major elements into two sets. Manganese was paired with $\mathrm{Ca}$, and $\mathrm{Mg}$ was paired with $\mathrm{Ni}$. This defined the second concentration parameter in the study. Silicon, as $\mathrm{SiO}_{2}$, was seen as essentially inert and not included in the pairings with the other semi-major elements. Mercury has been studied in other contexts. Therefore, mercury will be held at $1.5 \mathrm{wt} \%$ in the starting sludge total solids in all proposed tests in the sludge matrix study. The noble metals were added at the same concentration as were used in previous lower noble metal tests of the matrix sludges. $\mathrm{Cr}$ is typically at least an order of magnitude lower in concentration than the semi-major elements. It was considered potentially significant, however, due to its several oxidation states and was added to the Mg-Ni pair. Another constraint on handling the semi-major elements was that the sum of 
oxides must sum to $100 \%$. Suppressing or enhancing the concentrations of all of the semi-major elements simultaneously would have led to unreasonably high or low concentrations of either Al or Fe. Conceptually, the second concentration parameter represents reasonable compositional variations within each of the two main waste types, Purex or HM (Figure 1-1).

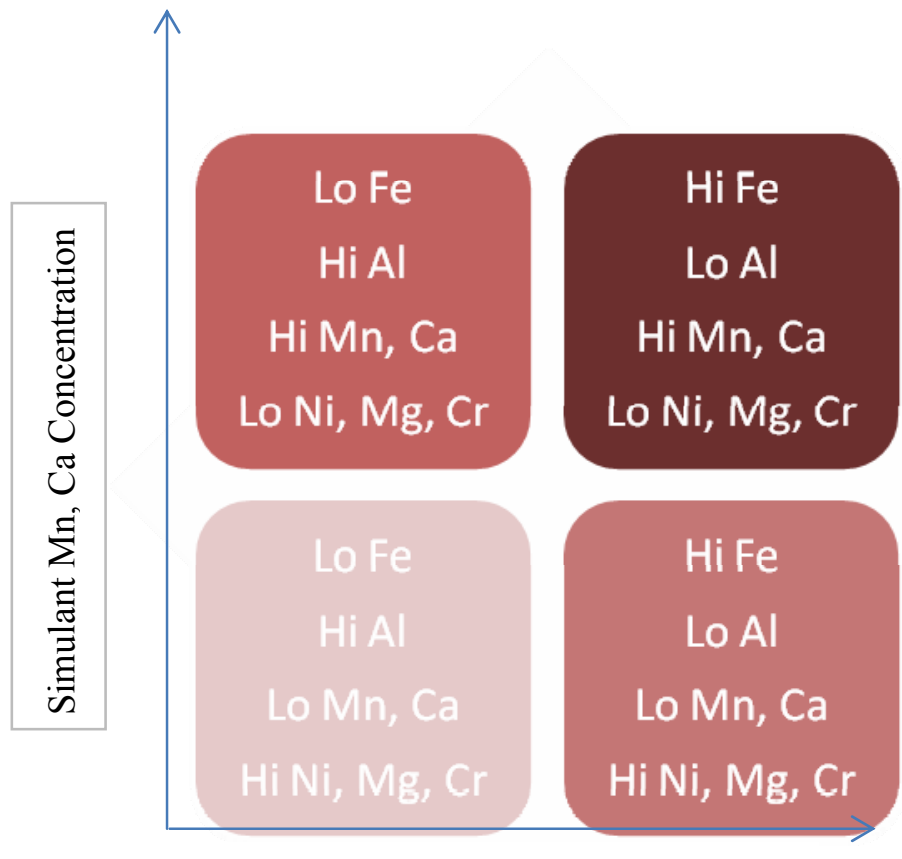

Simulant Fe Concentration

Figure 1-1. Definition of Sludge Matrix Simulants

The three primary parameter groups drawn from the insoluble solids are summarized below:

- High iron or high aluminum (representing Purex and HM wastes respectively). This parameter is referred to as either Hi Fe or Lo Fe in the discussion below.

- High $\mathrm{Mn}$ and $\mathrm{Ca}$ or high $\mathrm{Mg}, \mathrm{Ni}$, and $\mathrm{Cr}$ (representing the semi-major insoluble species). This parameter is referred to as either Hi Mn or Lo Mn below.

- The other (minor) sludge species, such as $\mathrm{Ba}, \mathrm{Zn}, \mathrm{Zr}, \mathrm{Cu}, \mathrm{La}$, etc., were to be held in constant relative proportions in the simulants.

- Supernate compositions of all four simulants were maintained nearly constant.

The following graphs compare the composition of Sludge Batches (SB) 3 to 6 with the matrix sludge simulants. The box in each graph outlines the compositional region for each of the four matrix simulants. Figure 1-2 graphs Fe versus Al, Figure 1-3 graphs Ni versus Al and Figure 1-4 graphs Mn versus Al. Note that the four simulants cannot bound the compositional region of all species but was designed to give a broad range of potential past and future processing for the most important species.

The sludge matrix simulations had identical mercury and noble metal targets, given in Table 1-2 as $\mathrm{wt} \%$ in the total solids of the trimmed slurry. The noble metals concentrations are comparable to the low noble metal case in the $\mathrm{Rh}-\mathrm{Ru}-\mathrm{Hg}$ matrix study, while mercury was held constant during the sludge simulant matrix study at the midpoint value of the $\mathrm{Rh}-\mathrm{Ru}-\mathrm{Hg}$ matrix study. ${ }^{8,9}$ 


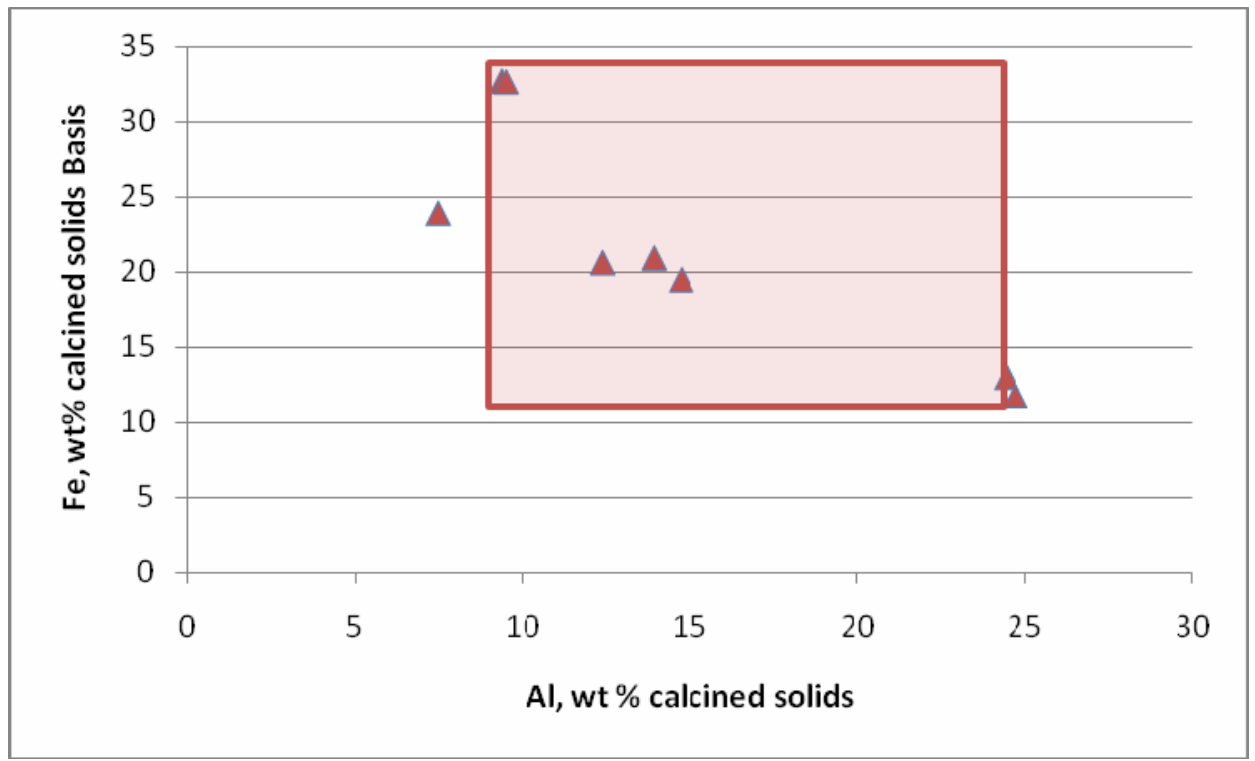

Figure 1-2. Al, Fe concentration in Sludge Batches SB3 to SB6 compared to Matrix Simulants

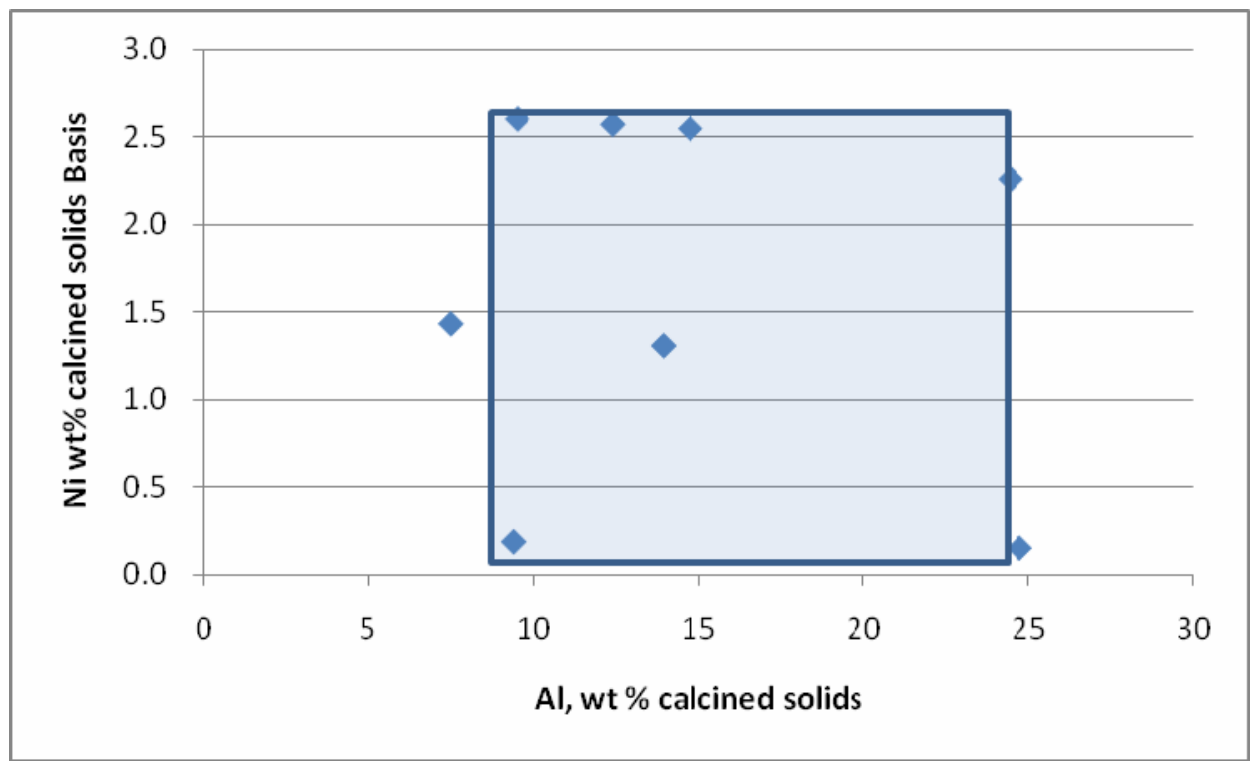

Figure 1-3. Al, Ni concentration in Sludge Batches SB3 to SB6 compared to Matrix Simulants 
SRNL-STI-2011-00275

Revision 0

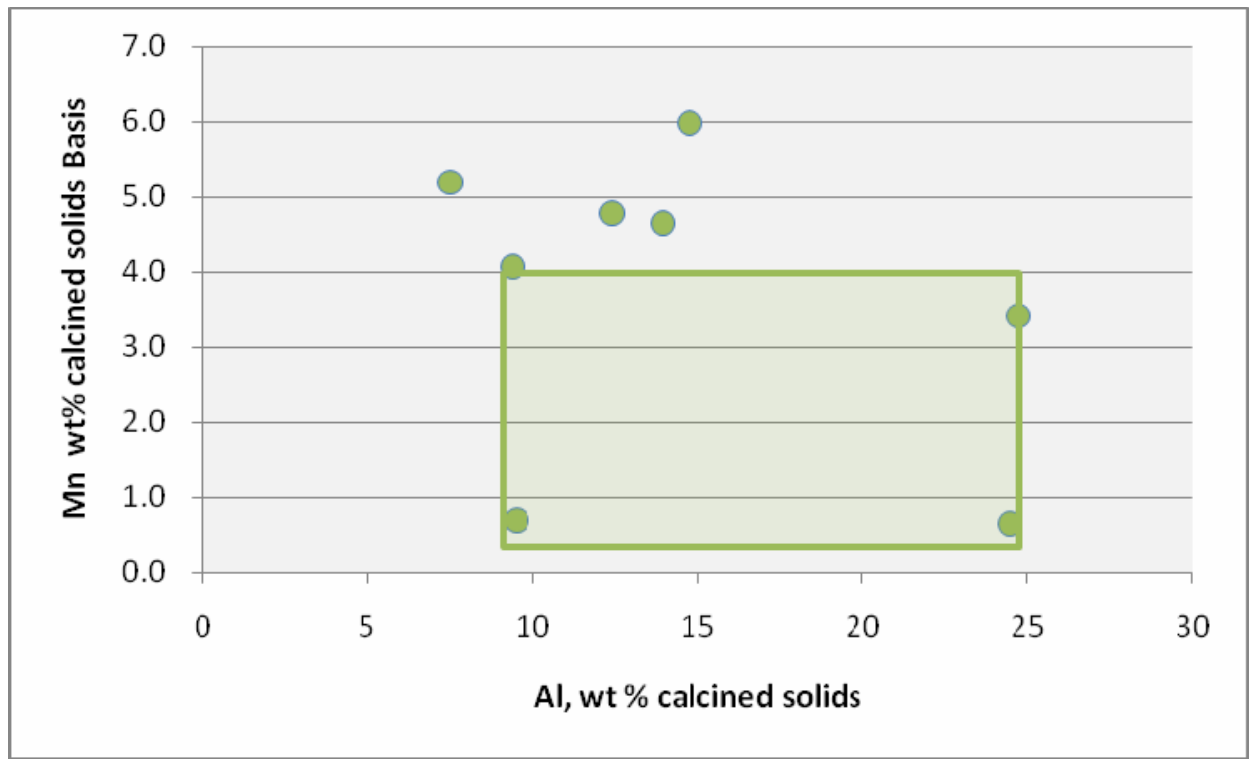

Figure 1-4. Al, Mn concentration in Sludge Batches SB3 to SB6 compared to Matrix Simulants

Table 1-1. Elemental Composition of Simulants Calcined at $1,100^{\circ} \mathrm{C}, \mathrm{wt} \%$

Table 1. Elemental composition of simulants calcined at $1100^{\circ} \mathrm{C}, \mathrm{wt}^{\circ}$

\begin{tabular}{|c|c|c|c|c|}
\hline Element & Hi Fe-Hi Mn & Hi Fe-Lo Mn & Lo Fe-Hi Mn & Lo Fe-Lo Mn \\
\hline $\mathrm{Al}$ & 9.18 & 9.32 & 23.4 & 24.1 \\
\hline $\mathrm{Ba}^{*}$ & 0.081 & 0.102 & 0.051 & 0.067 \\
\hline $\mathrm{Ca}$ & 3.86 & 2.08 & 3.38 & 1.86 \\
\hline $\mathrm{Ce}{ }^{*}$ & 0.104 & 0.106 & 0.115 & 0.095 \\
\hline $\mathrm{Cr}$ & 0.020 & 0.290 & 0.015 & 0.255 \\
\hline $\mathrm{Cu}^{*}$ & 0.054 & 0.053 & 0.052 & 0.048 \\
\hline $\mathrm{Fe}$ & 32.4 & 32.1 & 11.3 & 12.6 \\
\hline $\mathrm{K}^{*}$ & 0.110 & 0.076 & 0.134 & 0.097 \\
\hline $\mathrm{La}{ }^{*}$ & 0.050 & 0.049 & 0.017 & 0.045 \\
\hline $\mathrm{Mg}^{*}$ & 0.412 & 2.81 & 0.311 & 2.55 \\
\hline $\mathrm{Mn}^{*}$ & 4.06 & 0.694 & 3.59 & 0.671 \\
\hline $\mathrm{Na}^{*}$ & 13.2 & 13.8 & 16.6 & 2.27 \\
\hline $\mathrm{Ni}^{*}$ & 0.210 & 2.61 & 0.204 & 0.016 \\
\hline $\mathrm{P}^{*}$ & 0.014 & 0.014 & 0.016 & 0.070 \\
\hline $\mathrm{Pb}^{*}$ & 0.084 & 0.049 & 0.089 & 0.352 \\
\hline $\mathrm{S}^{*}$ & 0.290 & 0.295 & 0.356 & 1.37 \\
\hline $\mathrm{Si}^{*}$ & 1.56 & 1.55 & 1.42 & 0.032 \\
\hline $\mathrm{Sn}^{*}$ & 0.033 & 0.030 & 0.026 & 0.025 \\
\hline $\mathrm{Ti}^{*}$ & 0.026 & 0.026 & 0.023 & 0.058 \\
\hline $\mathrm{Zn}^{*}$ & 0.059 & 0.042 & 0.043 & 0.052 \\
\hline $\mathrm{Zr}^{*}$ & 0.058 & 0.122 & 050 & \\
\hline$*$ & & & & \\
\hline
\end{tabular}


Table 1-2. Mercury and Noble Metal Composition of Simulants Dried at $110^{\circ} \mathrm{C}$, wt $\%$

\begin{tabular}{c|c|} 
Element & $\begin{array}{c}\text { Concentration, } \\
\text { wt \% (solids } \\
\text { basis) }\end{array}$ \\
\hline $\mathrm{Hg}$ & 1.5 \\
\hline $\mathrm{Ag}$ & 0.0010 \\
\hline $\mathrm{Pd}$ & 0.0003 \\
\hline $\mathrm{Rh}$ & 0.0026 \\
\hline $\mathrm{Ru}$ & 0.1010 \\
\hline
\end{tabular}

\subsection{Testing Matrix}

A total of ten CPC simulations including SRAT and some SME cycles were performed. A more complete summary of the runs is included in Table 2-1.

Total boiling time in the SRAT cycles was calculated to remove mercury to $0.80 \mathrm{wt} \%$ in the total solids at a stripping rate of $750 \mathrm{lb}$ steam/lb $\mathrm{Hg}$ at the scaled maximum DWPF design rate of 5000 $\mathrm{lb} / \mathrm{hr}$ steam. Process samples were taken during the runs to monitor mercury concentration with time. Off-gas data were collected to monitor hydrogen as well as $\mathrm{CO}_{2}$ and $\mathrm{N}_{2} \mathrm{O}$ generation.

The amount of acid used in each simulation was calculated using the Koopman minimum acid equation. ${ }^{10}$ A stoichiometric factor of $100 \%$ was used for the low acid runs and a stoichiometric factor of $150 \%$ was used for the high acid runs. The Hsu equivalents for these runs are summarized in Table 1-3 below. REDOX was targeted at $0.1 \mathrm{Fe}^{+2} / \Sigma \mathrm{Fe}$ using a modified REDOX equation with a term for glycolate ion included ${ }^{4}$.

Table 1-3. Acid Stoichiometry of Matrix Sludge Runs

\begin{tabular}{|c|c|c|c|c|}
\hline Sludge & $\begin{array}{c}\text { Koopman } \\
\text { Stoichiometry }\end{array}$ & $\begin{array}{c}\text { Hsu } \\
\text { Stoichiometry }\end{array}$ & $\begin{array}{c}\text { Koopman } \\
\text { Stoichiometry }\end{array}$ & $\begin{array}{c}\text { Hsu } \\
\text { Stoichiometry }\end{array}$ \\
\hline HiFeLoMn & $100 \%$ & $117.5 \%$ & $150 \%$ & $176.6 \%$ \\
\hline HiFeHiMn & $100 \%$ & $103.6 \%$ & $150 \%$ & $155.4 \%$ \\
\hline LoFeLoMn & $100 \%$ & $112.7 \%$ & $150 \%$ & $169.0 \%$ \\
\hline LoFeHiMn & $100 \%$ & $102.9 \%$ & $150 \%$ & $154.4 \%$ \\
\hline
\end{tabular}




\subsection{Experimental Procedure}

The experimental apparatus used is typical for DWPF SRAT/SME testing. All experiments were performed in 4-L kettles. Test equipment included a gas chromatograph to measure offgas composition, an ammonia scrubber, and a $\mathrm{pH}$ meter. In all runs the SRNL acid calculation spreadsheet used the Koopman Equation to determine acid addition quantities and dewater targets.

\subsection{CPC Simulation Details}

The glycolic-formic flowsheet tests were performed at the ACTL using the four-liter kettle setup. The SRAT rigs were assembled following the guidelines of SRNL-PSE-2006-00074 ${ }^{11}$. The intent of the equipment is to functionally replicate the DWPF processing vessels. Each glass kettle is used to replicate both the SRAT and SME, and it is connected to the SRAT Condenser, the Mercury Water Wash Tank (MWWT), and the Formic Acid Vent Condenser (FAVC). The Slurry Mix Evaporator Condensate Tank (SMECT) is represented by a sampling bottle that is used to remove condensate through the MWWT. For the purposes of this paper, the condensers and wash tank are referred to as the offgas components. A sketch of the experimental setup is given as Figure 2-1.

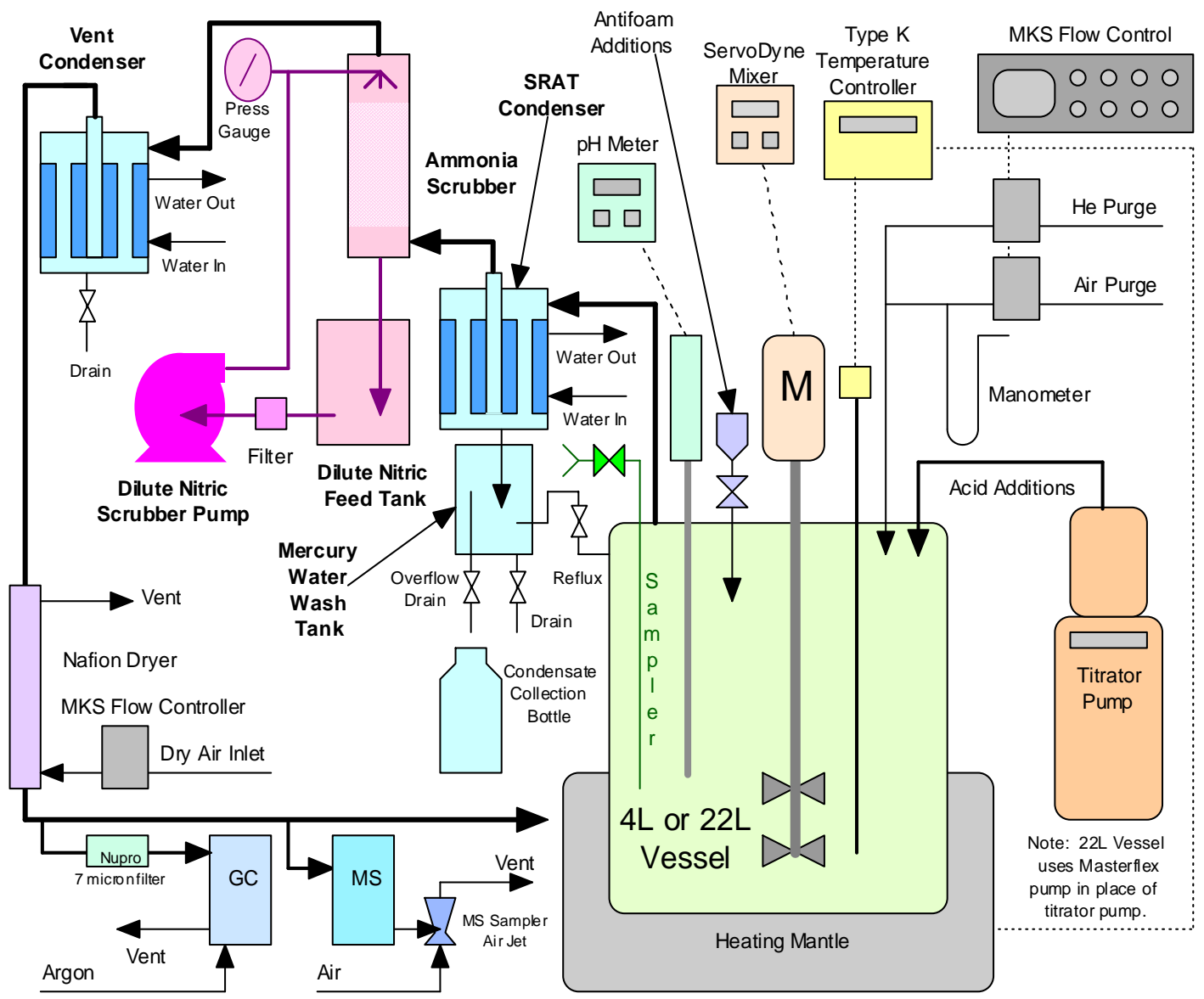




\section{Figure 2-1. Schematic of SRAT Equipment Set-Up}

The runs were performed using the guidance of Procedure ITS-0094 ${ }^{12}$ ("Laboratory Scale Chemical Process Cell Simulations") of Manual L29. Offgas hydrogen, oxygen, nitrogen, nitrous oxide, and carbon dioxide concentrations were measured during the experiments using in-line instrumentation. Nitrous dioxide was not measured but was calculated based on oxygen depletion. Helium was introduced at a concentration of $0.5 \%$ of the total air purge as an inert tracer gas so that total amounts of generated gas and peak generation rates could be calculated. This approach eliminates the impact of fugitive gas losses through small leaks on the calculated outlet gas flowrates. During the runs, the kettle was monitored to observe reactions that were occurring to include foaming, air entrainment, rheology changes, loss of heat transfer capabilities, and offgas carryover. Observations were recorded on data sheets and pasted into laboratory notebooks. ${ }^{13,14}$

Quality control measures were in place to qualify the data in this report. Helium and air purges were controlled using mass flow controllers calibrated by the SRNL calibration shop using NIST traceable standards and methods. Thermocouples were calibrated using a dry block calibrator. The GCs were calibrated with standard calibration gases. The $\mathrm{pH}$ probes were calibrated with $\mathrm{pH}$ 4 and $\mathrm{pH} 10$ buffers and rechecked at the conclusion of each run using $\mathrm{pH} \mathrm{4,7}$ and 10 buffer solutions.

The automated data acquisition system developed for the 4-L SRAT rigs was used to collect data electronically. Data included SRAT temperature, bath temperatures for the cooling water to the SRAT condenser and Formic Acid Vent Condenser (FAVC), slurry pH, SRAT mixer speed and torque, and air and helium purge flows (He is used as an internal standard and is set to $0.5 \%$ of the nominal SRAT air purge flow). Cumulative acid addition volume data were collected from the automated dispensers using an algorithm that matches the indicated total on the dispenser. Raw GC data were acquired on separate computers dedicated to each instrument.

Dual column Agilent 3000A micro GC's were used. The GC's were baked out before and between runs. Column-A can collect data related to $\mathrm{He}, \mathrm{H}_{2}, \mathrm{O}_{2}, \mathrm{~N}_{2}, \mathrm{NO}$, and $\mathrm{CO}$, while column-B can collect data related to $\mathrm{CO}_{2}, \mathrm{~N}_{2} \mathrm{O}$, and water. Calibrations were performed using a standard calibration gas containing 0.499 vol $\% \mathrm{He}, 1.000 \mathrm{vol} \% \mathrm{H}_{2}, 20.00$ vol $\% \mathrm{O}_{2}, 51.0 \mathrm{vol} \% \mathrm{~N}_{2}, 25.0$ vol $\% \mathrm{CO}_{2}$ and 2.50 vol $\% \mathrm{~N}_{2} \mathrm{O}$. Instrument calibration was verified prior to starting the SRAT cycle. Room air was used to give a two point calibration for $\mathrm{N}_{2}$. Calibration status was rechecked following the SRAT cycle.

Concentrated nitric acid (50-wt $\%)$, formic acid (90-wt\%) and glycolic acid (70 wt $\%)$-formic acid blends were used to acidify the sludge and perform neutralization and reduction reactions during processing. The amounts of acid to add for each run were determined using the Koopman acid equation. ${ }^{15}$ The acid mix was partitioned between nitric and the formic/glycolic blend by utilizing the latest REDOX equation ${ }^{16}$ with a term added for glycolate. A coefficient of 6 was used on the glycolate term based on electron equivalence. The REDOX target for these runs was 0.1 . The first principles electron equivalents expression had a new term added for glycolate ion (see below). To account for the reactions and anion destructions that occur during processing, assumptions about nitrite destruction, nitrite to nitrate conversion, formate destruction, and glycolate destruction were made for each run.

$$
\begin{gathered}
\text { REDOX }=0.2358+0.1999 *\left(\left(2 * \mathrm{C}_{\text {formate }}+4 * \mathrm{C}_{\text {oxalate }}+4 * \mathrm{C}_{\text {Carbon }}+6 * \mathrm{C}_{\text {glycolate }}-5 *\left(\mathrm{C}_{\text {Nitrate }}+\mathrm{C}_{\text {Nitrite }}\right)-\right.\right. \\
\left.\left.5 * \mathrm{C}_{\mathrm{Mn}}\right)\right) *(45 / \mathrm{TS})
\end{gathered}
$$


Where $\mathrm{C}=$ species concentration, $\mathrm{g}$-mole/ $\mathrm{kg}$ melter feed, $\mathrm{TS}=$ total solids in melter feed in wt \%, and REDOX is a molar ratio of $\mathrm{Fe}^{2+} / \Sigma \mathrm{Fe}$

To prevent foaming during SRAT processing, $200 \mathrm{ppm}$ Antifoam 747 was added before acid addition, $100 \mathrm{ppm}$ was added after nitric acid addition was complete and $500 \mathrm{ppm}$ was added at the completion of formic acid addition. SRAT processing included 15-hours at boiling (approximately 3-hours dewater time plus 12-hours reflux time). No SME cycle was performed. The SRAT condenser was maintained at $25^{\circ} \mathrm{C}$ during the run, while the vent condenser was maintained at $4^{\circ} \mathrm{C}$.

An ammonia scrubber was used for these simulations. The scrubber solution consisted of $749 \mathrm{~g}$ of de-ionized water and $1 \mathrm{~g}$ of $50 \mathrm{wt} \%$ nitric acid. The solution was recirculated through the column by a MasterFlex pump at $300 \mathrm{~mL} / \mathrm{min}$ through a spray nozzle at the top of the packed section. Glass rings were used as packing and did not significantly add to the back pressure on the SRAT vessel.

Process assumptions were made to predict SME product anion concentrations. In addition to the standard assumptions needed for formate loss and nitrite to nitrate conversion, a factor was added to the acid calculation for glycolate loss. Process assumptions for the runs were based on results from earlier glycolic acid/formic acid simulations.

\subsection{CPC Run Details}

The ten glycolic-formic flowsheet tests were performed at the ACTL using the four-liter kettle setup. Two runs were completed with each of the four matrix sludge simulants ( 8 total runs). Due to poor mixing and a low insoluble solids content in the SRAT product in the runs with the LoFeHiMn simulant, these two runs were repeated. Table 2-1 identifies each run and its corresponding assumptions.

Table 2-1. CPC Simulation Process Assumptions

\begin{tabular}{|c|c|c|c|c|} 
Run & Sludge & $\begin{array}{c}\text { Acid } \\
\text { Stoichiometry }\end{array}$ & Cycles & Date \\
\hline GF26 & HiFeLoMn & $100 \%$ & SRAT & 25-Jan-11 \\
\hline GF27 & HiFeLoMn & $150 \%$ & SRAT & 25-Jan-11 \\
\hline GF28 & HiFeHiMn & $100 \%$ & SRAT & 26-Jan-11 \\
\hline GF29 & HiFeHiMn & $150 \%$ & SRAT & 26-Jan-11 \\
\hline GF30 & LoFeLoMn & $100 \%$ & SRAT & 27-Jan-11 \\
\hline GF31 & LoFeLoMn & $150 \%$ & SRAT & 27-Jan-11 \\
\hline GF32 & LoFeHiMn & $100 \%$ & SRAT & 3-Feb-11 \\
\hline GF32A & LoFeHiMn & $100 \%$ & SRAT & 11-Mar-11 \\
\hline GF33 & LoFeHiMn & $150 \%$ & SRAT & 3-Feb-11 \\
\hline GF33A & LoFeHiMn & $150 \%$ & SRAT & 11-Mar-11 \\
\hline
\end{tabular}

DWPF design basis processing conditions were scaled down and used for most processing parameters including: SRAT/SME air purges, acid addition rates, and boil-up rate. SRAT product total dried solids were targeted at $25 \mathrm{wt} \%$ for all runs. 


\subsection{Process Data Collection}

In the experiments, an automated data acquisition system was used to collect run data every minute on a computer. In all experiments, the process data was manually recorded approximately every twenty minutes including SRAT slurry temperature, slurry $\mathrm{pH}$, cooling water temperatures for the SRAT condenser and Formic Acid Vent Condenser (FAVC), SRAT mixer speed, air and helium purge rates, and raw gas chromatographs.

\subsection{Analytical Methods}

Process samples were analyzed by various methods. Slurry and supernate elemental compositions were measured by inductively coupled plasma-atomic emission spectroscopy (ICPAES) at the Process Science Analytical Laboratory (PSAL). Soluble anion concentrations were measured by Ion Chromatography (IC). Mercury concentration was measured by ICP-AES. Ammonium ion concentration on selected samples was measured by cation chromatography by SRNL Analytical Development (AD). Slurry and supernate densities were measured using an Anton-Parr DMA-4500 instrument at PSAL. Reduction-Oxidation (REDOX) of glasses made from SME product slurries was measured by PSAL. Dewater and condensate samples were submitted to AD for volatile/semi-volatile organics analysis (VOA/SVOA).

A gradient method using the AG-11HC and AS-11HC, $2 \mathrm{~mm}$ microbore columns was developed to run IC samples for the Alternative Reductant Demonstrations. The method provides good peak resolution for all nine anions. The method was used to analyze fluoride, glycolate, formate, chloride, nitrite, nitrate, sulfate, oxalate and phosphate on samples at PSAL. 


\subsection{Results and Discussion}

The objective of the testing detailed in this document is to determine the viability of the glycolicformic acid flowsheet in processing sludge over a wide compositional range as requested by DWPF. Primary SRAT/SME simulation analytical data from the glycolic-formic acid flowsheet testing will be presented in the following sections and supplemental data will be included in the Appendices as necessary.

Ten 4-L Laboratory Scale experiments (GF26 to GF33A) were completed to determine the viability of the glycolic-formic acid flowsheet for DWPF over a wide sludge processing range. The results from experiments GF32 and GF33 will not be reported here as poor mixing compromised the results of these runs. Poor mixing led to settling of the slurry, which baked onto the glassware, causing overheating of the slurry in the bottom of the kettle. Both Runs GF32 and GF33 were repeated as Runs GF32A and GF33A because of the mixing issues.

\subsection{SRAT Chemistry}

The chemistry in the glycolic-formic SRAT cycle was very similar to the chemistry in the baseline nitric/formic acid flowsheet. However, there are a few areas where the chemistry is significantly different and these will be described below:

- The hydrogen generation in the glycolic-formic flowsheet was significantly lower compared to the baseline flowsheet. This will be discussed in Section 3.1.1.1.

- The formate destruction in the glycolic-formic flowsheet was significantly lower compared to the baseline flowsheet. This will be discussed in Section 3.1.2. This led to much lower carbon dioxide generation in the glycolic-formic flowsheet.

- The glycolic-formic flowsheet is much better at dissolving metals compared to the baseline flowsheet. This led to substantially lower yield stress SRAT products but also led to significant dissolution of metals such as iron and gadolinium which have been used to provide criticality control. This will be discussed in Section 3.1.3.

\subsubsection{SRAT Offgas}

The SRAT offgas was very similar for all four matrix sludges. Since the supernate was very similar for all four matrix sludges, this is expected. The even numbered runs were $100 \%$ acid stoichiometry and the odd numbered runs were $150 \%$ acid stoichiometry. It should be noted that the hydrogen, carbon dioxide and nitrous oxide were all low relative to typical baseline nitric/formic acid flowsheet runs.

\subsubsection{SRAT Hydrogen Suppression}

One of the main objectives of this flowsheet testing was to measure the SRAT cycle hydrogen generation for the glycolic/formic flowsheet over a wide sludge processing area. In the eight simulations below with the glycolic/formic flowsheet and mercury, hydrogen concentration in the off-gas never exceeded 0.046 volume percent $(<1 \%$ of the DWPF SRAT $0.65 \mathrm{lb} / \mathrm{hr}$ hydrogen limit). In all runs where hydrogen was detected, no hydrogen was detected until at least half way into the SRAT reflux. Table 3-1 and Figure 3-1 compare SRAT cycle hydrogen on a DWPF scale. In four of the eight runs, no hydrogen was detected at any time throughout the SRAT cycle. 
Table 3-1. Hydrogen Generation

\begin{tabular}{|l|c|c|c|c|c|c|c|c|c|}
\hline Run & GF26 & GF27 & GF28 & GF29 & GF30 & GF31 & GF32A & GF33A \\
\hline \hline Sludge & $\begin{array}{c}\text { HiFe } \\
\text { LoMn }\end{array}$ & $\begin{array}{c}\text { HiFe } \\
\text { LoMn }\end{array}$ & $\begin{array}{c}\text { HiFe } \\
\text { HiMn }\end{array}$ & $\begin{array}{c}\text { HiFe } \\
\text { HiMn }\end{array}$ & $\begin{array}{c}\text { LoFe } \\
\text { LoMn }\end{array}$ & $\begin{array}{c}\text { LoFe } \\
\text { LoMn }\end{array}$ & $\begin{array}{c}\text { LoFe } \\
\text { HiMn }\end{array}$ & $\begin{array}{c}\text { LoFe } \\
\text { HiMn }\end{array}$ \\
\hline Acid Stoichiometry & $100 \%$ & $150 \%$ & $100 \%$ & $150 \%$ & $100 \%$ & $150 \%$ & $100 \%$ & $150 \%$ \\
\hline \hline Max $\mathrm{H}_{2}, \mathrm{lb} / \mathrm{hr}$ DWPF & 0.0037 & 0.0028 & 0.0031 & 0.0000 & 0.0046 & 0.0000 & 0.0000 & 0.0000 \\
\hline Max $\mathrm{CO}_{2}, \mathrm{lb} / \mathrm{hr}$ DWPF & 151 & 221 & 473 & 235 & 469 & 212 & 545 & 271 \\
\hline \hline Max $\mathrm{N}_{2} \mathrm{O}, \mathrm{lb} / \mathrm{hr}$ DWPF & 11.9 & 16.0 & 32.4 & 18.2 & 14.0 & 9.1 & 15.2 & 3.8 \\
\hline
\end{tabular}

The highest hydrogen generation in the Glycolic-formic runs occurred in the runs with the lowest acid stoichiometry. This may be due to less adequate mixing in the lower acid runs, since they had thicker slurries, which makes them harder to keep the insoluble solids suspended. These solids likely collected in hotter regions on the bottom of the kettle which may have led to higher generation of hydrogen. In these runs the minimum hydrogen detection limit was $0.003 \mathrm{~mol} \%$ and the maximum hydrogen detected was $0.005 \mathrm{~mol} \%$.

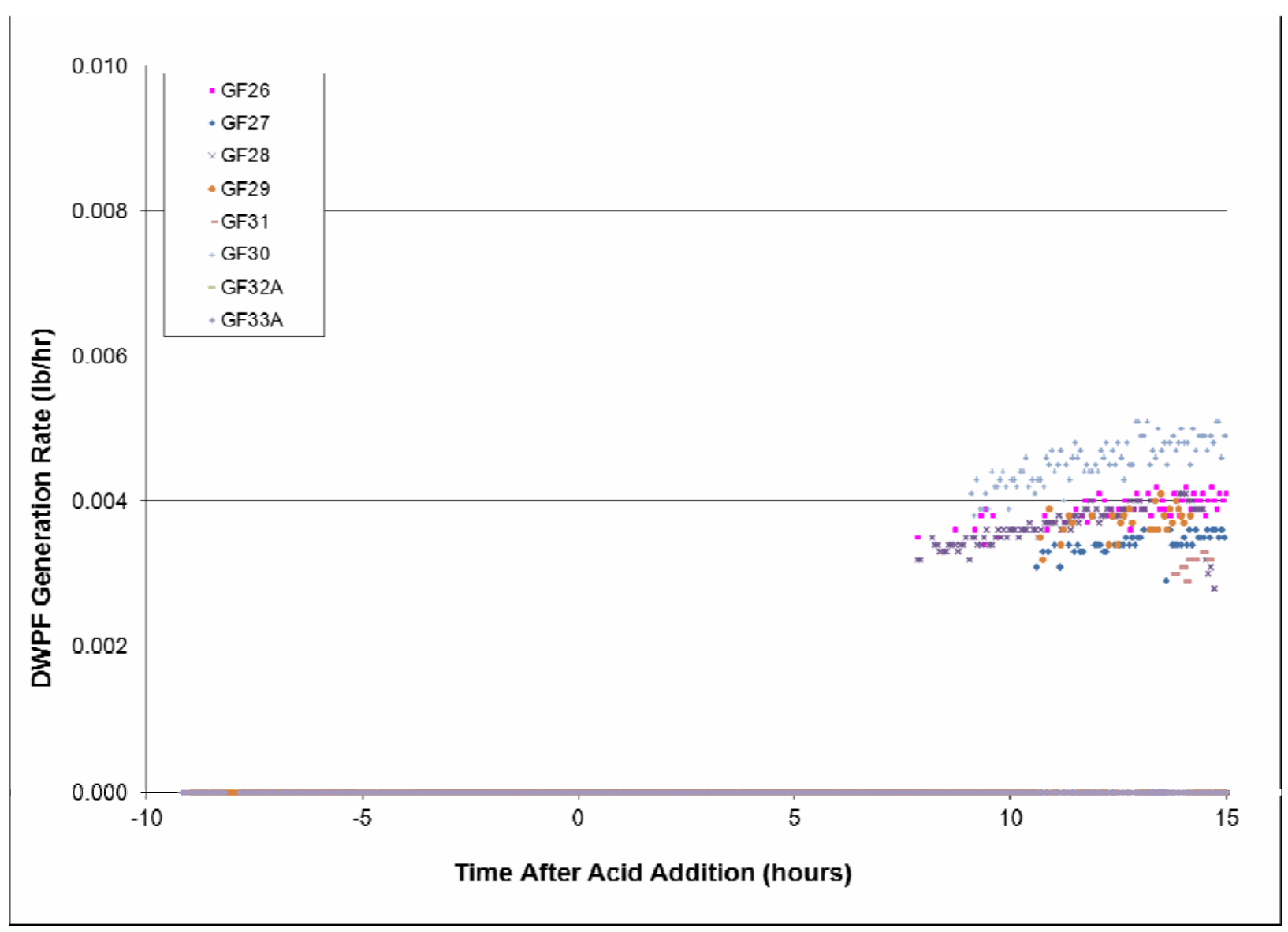

Figure 3-1. SRAT cycle $\mathrm{H}_{2}$ generation 


\subsubsection{Other SRAT Offgas Generation}

Besides essentially eliminating hydrogen generation, the glycolic/formic acid flowsheet also appears to significantly slow down other off-gas generating reactions, namely $\mathrm{N}_{2} \mathrm{O}$ and $\mathrm{CO}_{2}$. The graphs below compare $\mathrm{N}_{2} \mathrm{O}$ (Figure 3-2) and $\mathrm{CO}_{2}$ (Figure 3-3) generation rates for the matrix study runs.

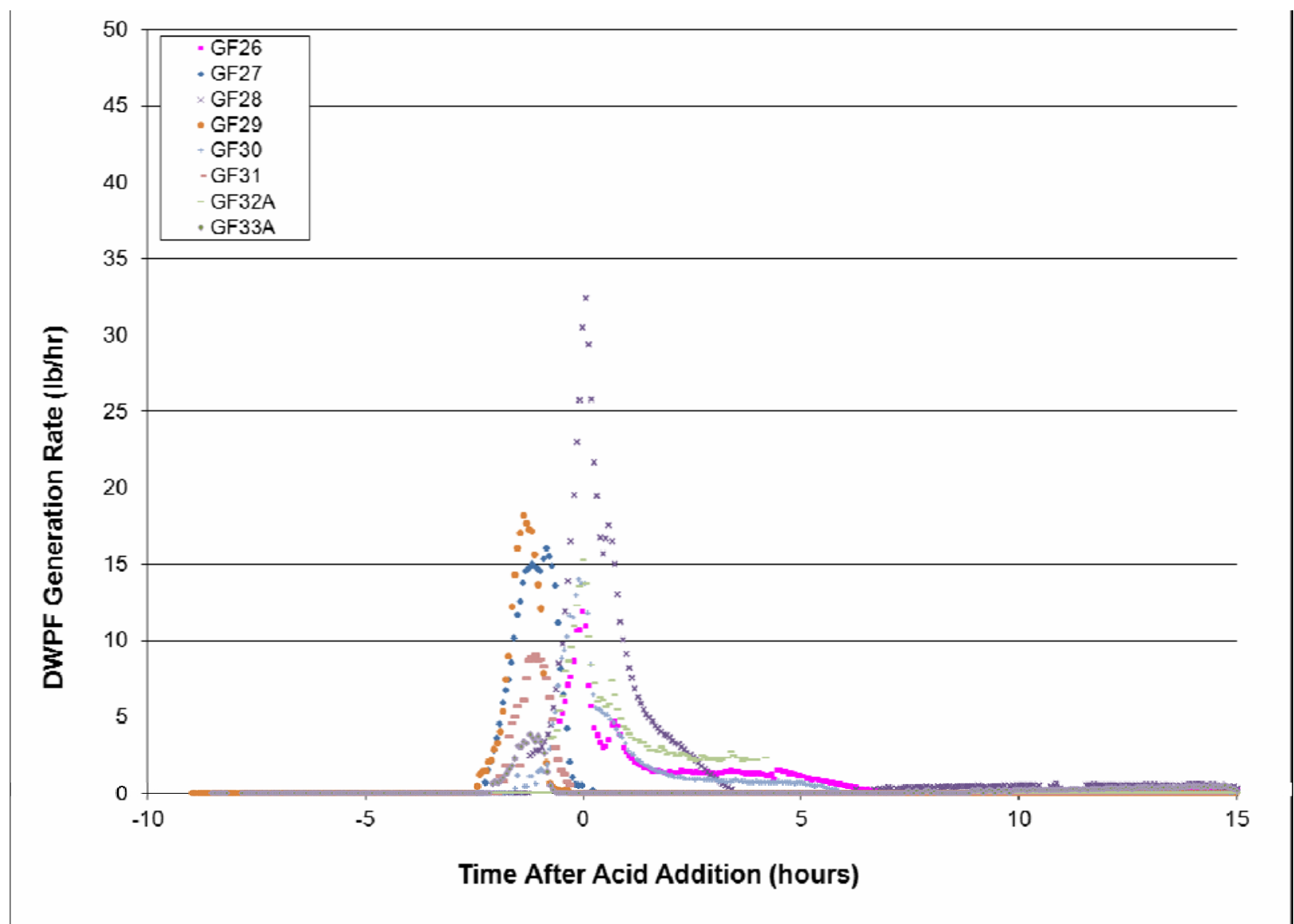

Figure 3-2. SRAT cycle $\mathrm{N}_{2} \mathrm{O}$ generation 
SRNL-STI-2011-00275

Revision 0

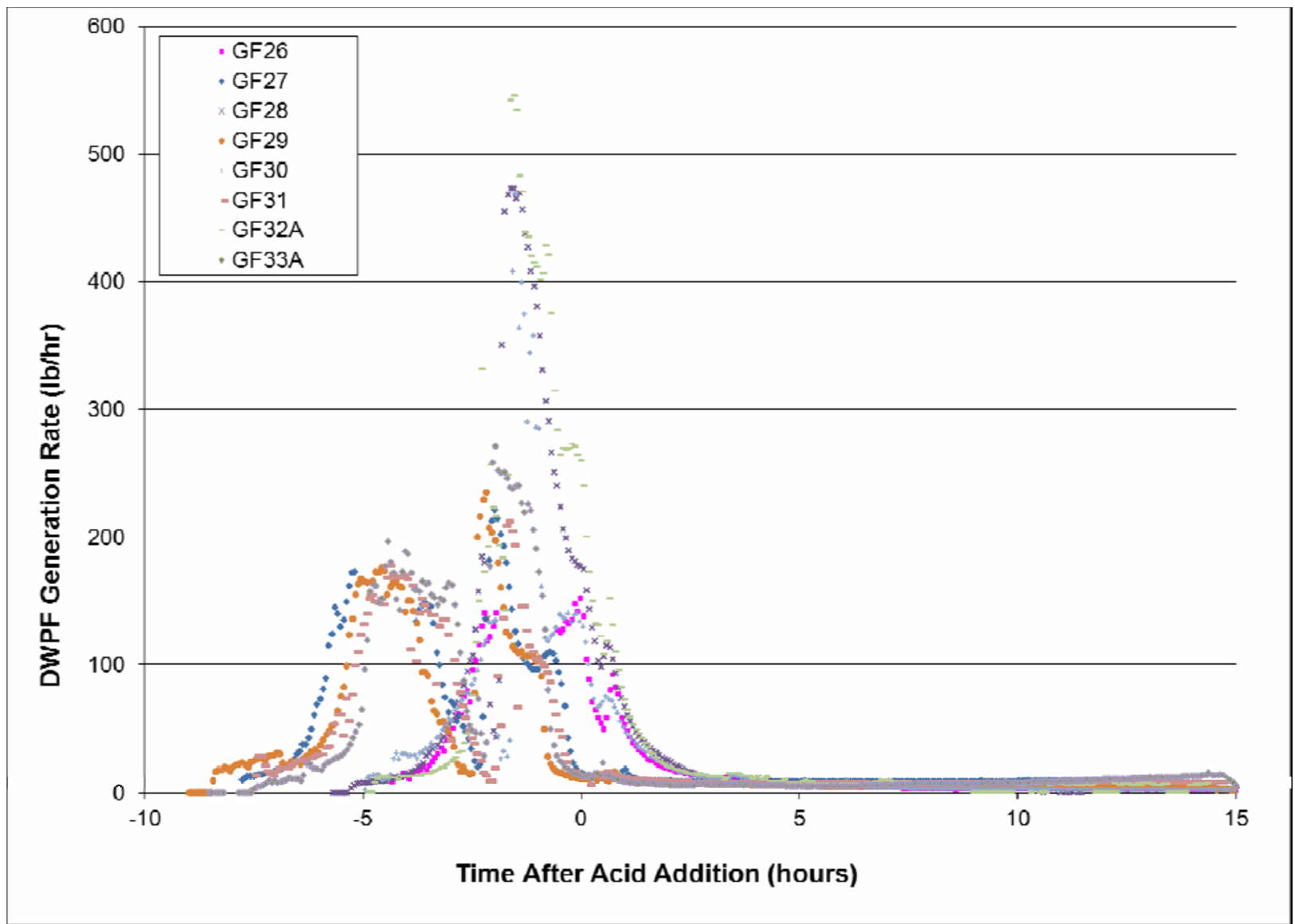

Figure 3-3. SRAT cycle $\mathrm{CO}_{2}$ generation

\subsubsection{SRAT Product Data}

General SRAT product data for the first eight runs are tabulated below (Table 3-2). The even numbered runs were the lower acid stoichiometry runs (100\%), while the odd numbered runs were the higher acid stoichiometry runs $(150 \%)$.

The glycolate, nitrate and formate are generally higher in the $150 \%$ acid stoichiometry runs. In addition, the soluble solids is significantly higher in the $150 \%$ acid stoichiometry runs, with the exception of the HiAlLoMn runs (GF30,31). Also, the HiAlHiMn had a smaller increase in soluble solids comparing the $100 \%$ to $150 \%$ acid stoichiometry run (GF32A, GF33A) compared to the HiFe runs (GF26-29)

The sulfate measured by IC was likely inaccurate. The sulfate concentration as calculated from the ICP-AES Sulfur measurement was significantly lower than the IC sulfate in all runs. This data was added below the sulfate row in Table 3-2. 
Table 3-2. SRAT Product Anions, Solids, Density, and pH Data

\begin{tabular}{|c|c|c|c|c|c|c|c|c|}
\hline anions (mg/kg) & GF26 & GF27 & GF28 & GF29 & GF30 & GF31 & GF32A & GF33A \\
\hline fluoride & $<100$ & $<100$ & $<100$ & $<100$ & $<100$ & $<100$ & $<100$ & $<100$ \\
\hline chloride & 354.5 & 314.0 & 342.5 & 299.0 & 346.5 & 326.5 & 401.0 & 300.5 \\
\hline nitrite & $<100$ & $<100$ & $<100$ & $<100$ & $<100$ & $<100$ & $<100$ & $<100$ \\
\hline nitrate & 62,350 & 81,400 & 55,700 & 79,300 & 59,450 & 83,050 & 56,800 & 78,050 \\
\hline sulfate & 833 & 1,100 & 1,400 & 1,055 & 1,015 & 1,485 & 2,075 & 3,760 \\
\hline Sulfate from ICP-AES S & 1,378 & 1,325 & 1,352 & 1,476 & 1,488 & 1,360 & 1,612 & 1,456 \\
\hline glycolate & 27,900 & 52,400 & 35,350 & 57,600 & 38,800 & 67,700 & 46,700 & 51,950 \\
\hline oxalate & $<100$ & 1,760 & 280 & 2,090 & $<100$ & 663 & 209 & 757 \\
\hline formate & 3,085 & 4,205 & 5,010 & 6,600 & 2,765 & 6,060 & $<100$ & $<100$ \\
\hline phosphate & $<100$ & $<100$ & $<100$ & $<100$ & $<100$ & $<100$ & $<100$ & $<100$ \\
\hline Total Solids & $29.10 \%$ & $28.14 \%$ & $30.19 \%$ & $27.79 \%$ & $29.26 \%$ & $28.55 \%$ & $29.75 \%$ & $29.66 \%$ \\
\hline Insoluble Solids & $17.94 \%$ & $12.18 \%$ & $19.32 \%$ & $11.96 \%$ & $17.03 \%$ & $20.04 \%$ & $17.54 \%$ & $15.98 \%$ \\
\hline Calcined Solids & $16.89 \%$ & $15.41 \%$ & $17.95 \%$ & $15.62 \%$ & $16.29 \%$ & $14.72 \%$ & $16.77 \%$ & $15.09 \%$ \\
\hline Supernate Solids & $13.61 \%$ & $18.17 \%$ & $13.48 \%$ & $17.98 \%$ & $14.74 \%$ & $10.65 \%$ & $14.80 \%$ & $16.28 \%$ \\
\hline Soluble Solids & $11.17 \%$ & $15.95 \%$ & $10.88 \%$ & $15.83 \%$ & $12.23 \%$ & $8.51 \%$ & $12.21 \%$ & $13.68 \%$ \\
\hline Slurry Density, $\mathrm{g} / \mathrm{mL}$ & 1.190 & 1.227 & 1.229 & 1.206 & 1.201 & 1.221 & 1.206 & 1.168 \\
\hline Supernate Density, $\mathrm{g} / \mathrm{mL}$ & 1.091 & 1.134 & 1.091 & 1.137 & 1.099 & 1.138 & 1.098 & 1.120 \\
\hline $\mathrm{pH}$ & 5.89 & 3.10 & 5.49 & 2.68 & 5.12 & 2.91 & 6.05 & 3.06 \\
\hline
\end{tabular}

Anion balance data for nitrite, nitrate, formate and glycolate are presented in the table below for runs GF26-33A (Table 3-3).

Table 3-3. Anion Balance Data

\begin{tabular}{|l|l|l|l|l|l|l|l|l|}
\hline Anion Conversion & GF26 & GF27 & GF28 & GF29 & GF30 & GF31 & GF32A & GF33A \\
\hline \% SRAT Formate Destruction & 60.4 & 56.2 & 37.3 & 32.5 & 65.0 & 34.9 & 100.0 & 100.0 \\
\hline $\begin{array}{l}\text { \% SRAT Glycolate } \\
\text { Destruction }\end{array}$ & 47.1 & 19.6 & 34.7 & 13.1 & 27.6 & -7.3 & 24.7 & 27.5 \\
\hline \% SRAT Nitrite Destruction & 100 & 100 & 100 & 100 & 100 & 100 & 100 & 100 \\
\hline \% nitrite conversion to nitrate & 45.0 & 44.5 & 39.8 & 58.8 & 27.8 & 59.5 & 7.57 & 20.1 \\
\hline
\end{tabular}

SRAT (Table 3-4) product elemental data are summarized in the following tables. 
Table 3-4. SRAT Product Elemental Data, wt \% calcined solids basis

\begin{tabular}{|c|c|c|c|c|c|c|c|c|}
\hline element & GF26 & GF27 & GF28 & GF29 & GF30 & GF31 & GF32A & GF33A \\
\hline Al & 9.29 & 9.13 & 9.11 & 9.21 & 23.35 & 23.15 & 25.11 & 24.90 \\
\hline Ba & 0.09 & 0.09 & 0.08 & 0.08 & 0.06 & 0.06 & 0.06 & 0.06 \\
\hline Ca & 2.12 & 2.09 & 4.43 & 3.88 & 1.81 & 1.87 & 2.80 & 2.86 \\
\hline Cd & $<0.010$ & $<0.010$ & $<0.010$ & $<0.010$ & $<0.010$ & $<0.010$ & $<0.010$ & $<0.010$ \\
\hline $\mathrm{Cr}$ & 0.26 & 0.26 & 0.02 & 0.02 & 0.22 & 0.22 & $<0.010$ & $<0.010$ \\
\hline $\mathrm{Cu}$ & 0.04 & 0.04 & 0.04 & 0.04 & 0.04 & 0.04 & 0.03 & 0.03 \\
\hline Fe & 31.80 & 31.35 & 33.00 & 32.15 & 12.30 & 12.40 & 10.89 & 10.99 \\
\hline Gd & 0.62 & 0.08 & 0.60 & $<0.010$ & 0.22 & 0.08 & 0.22 & 0.22 \\
\hline $\mathbf{K}$ & 0.08 & 0.09 & 0.09 & 0.11 & 0.08 & 0.09 & 0.10 & 0.12 \\
\hline $\mathbf{L i}$ & $<0.100$ & $<0.100$ & $<0.100$ & $<0.100$ & $<0.100$ & $<0.100$ & 0.13 & 0.13 \\
\hline Mg & 2.71 & 2.71 & 0.40 & 0.40 & 2.43 & 2.46 & 0.34 & 0.35 \\
\hline Mn & 0.62 & 0.62 & 3.75 & 4.01 & 0.58 & 0.57 & 2.97 & 2.98 \\
\hline $\mathrm{Na}$ & 12.75 & 12.65 & 11.85 & 12.50 & 13.85 & 13.75 & 15.95 & 16.32 \\
\hline $\mathbf{N i}$ & 2.63 & 2.59 & 0.18 & 0.18 & 2.30 & 2.35 & 0.15 & 0.15 \\
\hline $\mathbf{P}$ & $<0.100$ & $<0.100$ & $<0.100$ & $<0.100$ & $<0.100$ & $<0.100$ & $<0.100$ & $<0.100$ \\
\hline $\mathbf{P b}$ & $<0.100$ & $<0.100$ & $<0.100$ & $<0.100$ & $<0.100$ & $<0.100$ & $<0.010$ & $<0.010$ \\
\hline $\mathbf{S}$ & 0.27 & 0.29 & 0.25 & 0.32 & 0.31 & 0.31 & 0.32 & 0.32 \\
\hline Si & 1.59 & 1.55 & 1.56 & 1.56 & 1.37 & 1.38 & 1.51 & 1.59 \\
\hline Sn & 0.08 & NM & $<0.010$ & NM & 0.08 & NM & $<0.010$ & $<0.010$ \\
\hline $\mathbf{T i}$ & 0.01 & 0.01 & 0.01 & 0.01 & 0.01 & 0.01 & $<0.010$ & $<0.010$ \\
\hline Zn & 0.07 & 0.07 & 0.06 & 0.06 & 0.06 & 0.06 & 0.05 & 0.05 \\
\hline $\mathrm{Zr}$ & 0.11 & 0.11 & 0.05 & 0.05 & 0.04 & 0.04 & 0.06 & 0.06 \\
\hline
\end{tabular}

$\mathrm{NM}=$ Not Measured 
Table 3-5. SRAT Product Filtrate Elemental Data, mg/L

\begin{tabular}{|l|l|l|l|l|l|l|l|l|}
\hline element & GF26 & GF27 & GF28 & GF29 & GF30 & GF31 & GF32A & GF33A \\
\hline $\mathbf{A l}$ & 31.55 & 3,785 & 39.05 & 3,480 & 174.50 & 5,280 & 73.87 & 3,740 \\
\hline $\mathbf{B a}$ & 1.85 & 3.18 & 1.68 & 4.39 & 1.27 & 2.60 & $<1.00$ & 2.15 \\
\hline $\mathbf{C a}$ & 3,205 & 4,100 & 3,620 & 7,680 & 2,305 & 3,580 & 1,870 & 5,455 \\
\hline $\mathbf{C d}$ & $<0.100$ & $<0.100$ & $<0.100$ & $<0.100$ & $<0.100$ & $<0.100$ & $<1.00$ & $<1.00$ \\
\hline $\mathbf{C r}$ & 0.49 & 81.90 & 0.19 & 6.47 & 5.81 & 194.50 & $<1.00$ & 3.86 \\
\hline $\mathbf{C u}$ & 0.76 & 43.00 & 0.75 & 30.75 & 3.03 & 45.90 & 1.53 & 48.14 \\
\hline $\mathbf{F e}$ & 17.35 & 6,920 & 58.15 & 8,350 & 46.60 & 5,595 & 34.67 & 3,010 \\
\hline $\mathbf{G d}$ & 36.30 & 902.50 & 45.00 & 1040.00 & 107.50 & 399.50 & 32.11 & 402.45 \\
\hline $\mathbf{K}$ & 294.50 & 300.00 & 367.50 & 377.0 & 316.5 & 289.5 & 443.65 & 434.20 \\
\hline $\mathbf{L i}$ & $<10.0$ & $<0.100$ & $<10.0$ & $<0.100$ & $<10.0$ & $<0.100$ & 1.85 & 1.92 \\
\hline $\mathbf{M g}$ & 3,215 & 4,970 & 231.0 & 387.0 & 1,030 & 4,375 & 274.15 & 329.75 \\
\hline $\mathbf{M n}$ & 637.5 & 1,330 & 6,220 & 7,560 & 972 & 1,250 & 5,650 & 3,515 \\
\hline $\mathbf{N a}$ & & & \multicolumn{2}{|c|}{ Not Measured } & & & 34,850 & 31,700 \\
\hline $\mathbf{N i}$ & 290.00 & 4,010 & 11.20 & 137.5 & 1,120 & 4,025 & 10.62 & 178.10 \\
\hline $\mathbf{P}$ & $<10.0$ & $<10.0$ & $<10.0$ & $<10.0$ & $<10.0$ & $<10.0$ & $<10.0$ & $<10.0$ \\
\hline $\mathbf{P b}$ & 0.71 & 3.68 & 1.10 & 7.72 & 1.04 & 29.00 & 1.65 & 55.69 \\
\hline $\mathbf{S}$ & 427.50 & 376 & 575 & 362.5 & 555 & 494.5 & 596.0 & 390 \\
\hline $\mathbf{S i}$ & 109.0 & 79.00 & 94.30 & 77.05 & 120.0 & 120.0 & 30.18 & 90.75 \\
\hline $\mathbf{S n}$ & 21.10 & 21.10 & 1.56 & 1.56 & 2.34 & 56.40 & 3.08 & 0.90 \\
\hline $\mathbf{T i}$ & 0.10 & 0.13 & 0.10 & 0.14 & 0.11 & 0.18 & $<1.00$ & $<1.00$ \\
\hline $\mathbf{Z n}$ & 0.84 & 52.40 & $<0.100$ & 40.75 & 8.04 & 68.85 & $<1.00$ & 50.14 \\
\hline $\mathbf{Z r}$ & 0.54 & 98.35 & 0.50 & 46.15 & 2.69 & 53.10 & 1.32 & 64.50 \\
\hline
\end{tabular}

\subsubsection{SRAT Dissolution of Metals}

The higher the acid stoichiometry, the more metals were dissolved in the SRAT product. The addition of glycolic acid in the glycolic-formic flowsheet runs caused some elements that are traditionally insoluble to become soluble. $\mathrm{Al}, \mathrm{Ca}, \mathrm{Cu}, \mathrm{Fe}, \mathrm{Mg}, \mathrm{Mn}, \mathrm{Ni}, \mathrm{Si}, \mathrm{Sr}$, and $\mathrm{Zr}$ are much more soluble in the formic-glycolic flowsheet runs. The data is summarized in Table 3-6.

There is a significant difference in the dissolution of metals in comparing the $100 \%$ stoichiometry runs to the $150 \%$ stoichiometry runs. In the HiFeLoMn runs (GF26 and GF27), $\mathrm{Ni}$ is $\sim 5 \%$ soluble in the GF26 and 78\% soluble in GF27. $\mathrm{Cu}, \mathrm{Gd}$, and $\mathrm{Zn}$ have similar patterns.

A number of the metals have calculated $\%$ dissolved of $>100 \%$. The table lists $>100 \%$ but the $\%$ dissolved can't exceed 100\%. Gd, Mn and $\mathrm{K}$ all have \% element dissolved of $>100 \%$, particularly for the high acid stoichiometry runs. 
Table 3-6. SRAT Product Supernate \% of Element Dissolved

\begin{tabular}{|c|c|c|c|c|c|c|c|c|}
\hline element & GF26 & GF27 & GF28 & GF29 & GF30 & GF31 & GF32A & GF33A \\
\hline Al & $0.15 \%$ & $20.84 \%$ & $0.18 \%$ & $18.73 \%$ & $0.35 \%$ & $10.89 \%$ & $0.13 \%$ & $7.47 \%$ \\
\hline Ba & $0.90 \%$ & $1.76 \%$ & $0.89 \%$ & $2.88 \%$ & $0.96 \%$ & $2.09 \%$ & $<\mathrm{MDL}$ & $1.66 \%$ \\
\hline Ca & $67.31 \%$ & $98.78 \%$ & $33.70 \%$ & $98.25 \%$ & $59.18 \%$ & $91.66 \%$ & $29.96 \%$ & $94.86 \%$ \\
\hline $\mathrm{Cr}$ & $0.08 \%$ & $15.64 \%$ & $0.37 \%$ & $17.82 \%$ & $1.24 \%$ & $43.20 \%$ & $<\mathrm{MDL}$ & $<\mathrm{MDL}$ \\
\hline $\mathbf{C u}$ & $0.78 \%$ & $52.05 \%$ & $0.75 \%$ & $36.73 \%$ & $3.55 \%$ & $50.39 \%$ & $2.05 \%$ & $71.31 \%$ \\
\hline Fe & $0.02 \%$ & $11.09 \%$ & $0.07 \%$ & $12.88 \%$ & $0.18 \%$ & $21.55 \%$ & $0.14 \%$ & $13.61 \%$ \\
\hline Gd & $2.62 \%$ & $>100 \%$ & $3.10 \%$ & $<\mathrm{MDL}$ & $23.12 \%$ & $>100 \%$ & $6.65 \%$ & $89.27 \%$ \\
\hline $\mathbf{K}$ & $>100 \%$ & $>100 \%$ & $>100 \%$ & $>100 \%$ & $>100 \%$ & $>100 \%$ & $>100 \%$ & $>100 \%$ \\
\hline Mg & $52.9 \%$ & $92.3 \%$ & $24.0 \%$ & $47.7 \%$ & $19.64 \%$ & $85.10 \%$ & $35.82 \%$ & $47.00 \%$ \\
\hline Mn & $46.08 \%$ & $>100 \%$ & $68.42 \%$ & $93.46 \%$ & $78.07 \%$ & $>100 \%$ & $85.36 \%$ & $58.72 \%$ \\
\hline $\mathrm{Na}$ & \multicolumn{6}{|c|}{ Not Measured } & $97.91 \%$ & $96.53 \%$ \\
\hline $\mathbf{N i}$ & $4.92 \%$ & $77.77 \%$ & $2.50 \%$ & $38.19 \%$ & $22.62 \%$ & $81.79 \%$ & $3.24 \%$ & $58.25 \%$ \\
\hline $\mathbf{S}$ & $69.85 \%$ & $65.81 \%$ & $94.19 \%$ & $56.96 \%$ & $84.33 \%$ & $76.54 \%$ & $83.18 \%$ & $60.23 \%$ \\
\hline Si & $3.05 \%$ & $2.57 \%$ & $2.50 \%$ & $2.45 \%$ & $4.07 \%$ & $4.15 \%$ & $0.89 \%$ & $2.83 \%$ \\
\hline $\mathbf{T i}$ & $0.36 \%$ & $0.55 \%$ & $0.33 \%$ & $0.63 \%$ & $0.49 \%$ & $0.85 \%$ & $<\mathrm{MDL}$ & $<\mathrm{MDL}$ \\
\hline $\mathbf{Z n}$ & $0.56 \%$ & $39.29 \%$ & $<\mathrm{MDL}$ & $34.24 \%$ & $6.65 \%$ & $58.71 \%$ & $<\mathrm{MDL}$ & $51.97 \%$ \\
\hline $\mathbf{Z r}$ & $0.22 \%$ & $46.83 \%$ & $0.40 \%$ & $47.66 \%$ & $3.00 \%$ & $68.53 \%$ & $1.06 \%$ & $50.36 \%$ \\
\hline
\end{tabular}

Of particular concern is iron and gadolinium solubility because criticality control at DWPF is based on iron and plutonium not partitioning between the solids and supernate. It should be noted that metals such as $\mathrm{Fe}$ and $\mathrm{Gd}$ dissolve and reprecipitate during processing so the percent soluble can change throughout a run.

\subsubsection{SRAT pH profile}

Time dependent SRAT $\mathrm{pH}$ data were collected throughout the sludge matrix study runs. The graph below shows the $\mathrm{pH}$ trends from the runs (all containing mercury and noble metals). Note that the $\mathrm{pH}$ remained approximately 5 during SRAT boiling for the $100 \%$ acid stoichiometry runs and 3 for the $150 \%$ acid stoichiometry runs. The data is summarized in Figure 3-4. 


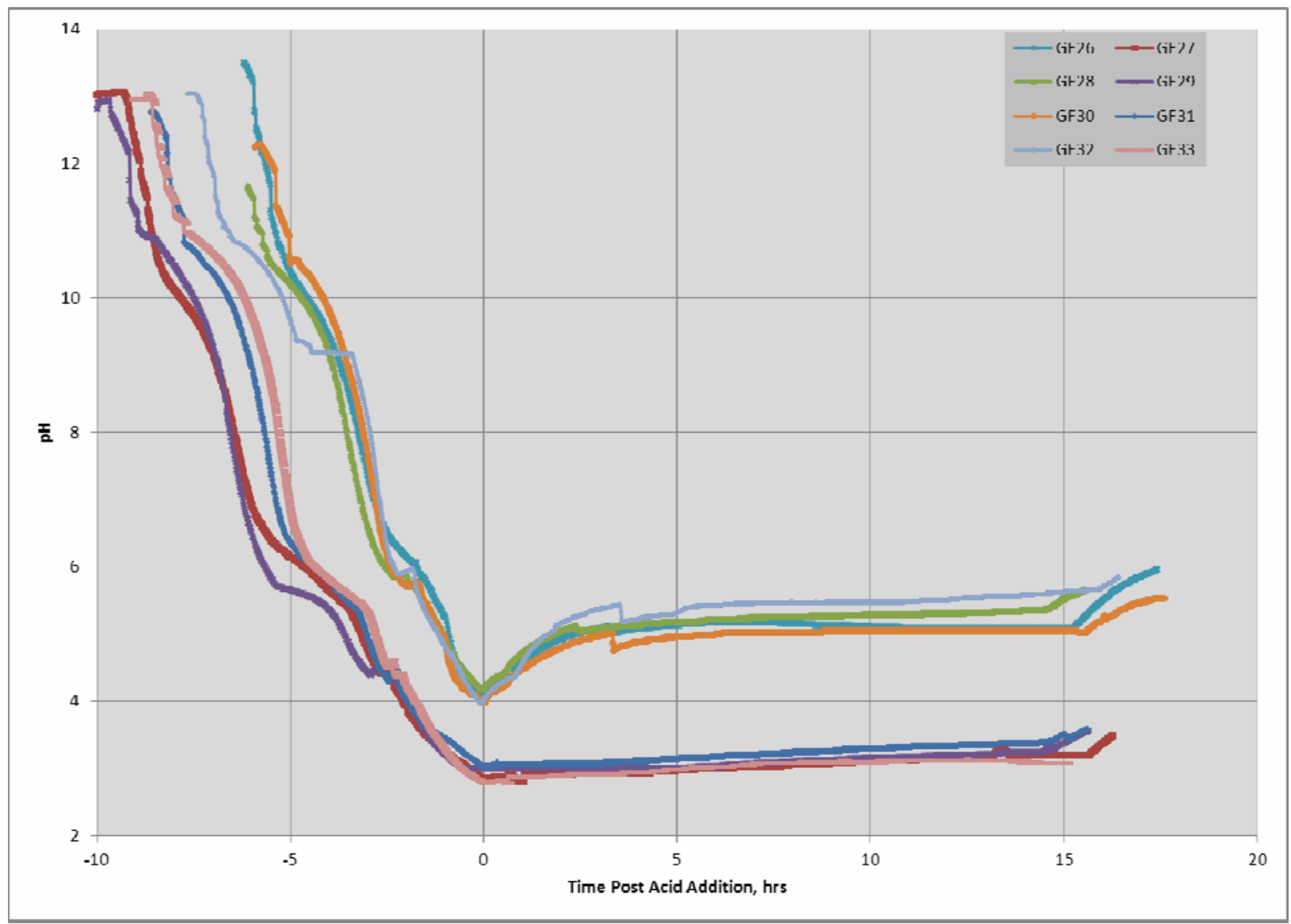

Figure 3-4. $\mathrm{pH}$ Trends for Matrix Study SRAT Runs

\subsubsection{SRAT Mercury Reduction}

In all runs the measured mercury in the SRAT products was well below the DWPF mercury limit of $0.80 \mathrm{wt} \%$ on a total solids basis $(2,160 \mathrm{mg} / \mathrm{kg}$ at $27 \mathrm{wt} \%$ total solids $)$ after fifteen hours of boiling. This is not surprising as the runs all started at $1.5 \mathrm{wt} \% \mathrm{Hg}$ on a total solids basis and recent testing has shown that the mercury can settle out in the SRAT kettle, underestimating the mercury concentration in the kettle.

Samples were taken periodically throughout the runs for mercury analysis. The chart below (Figure 3-5) shows the concentration of mercury in the slurry as a function of time for all runs. The mercury data is summarized in Appendix A1. 


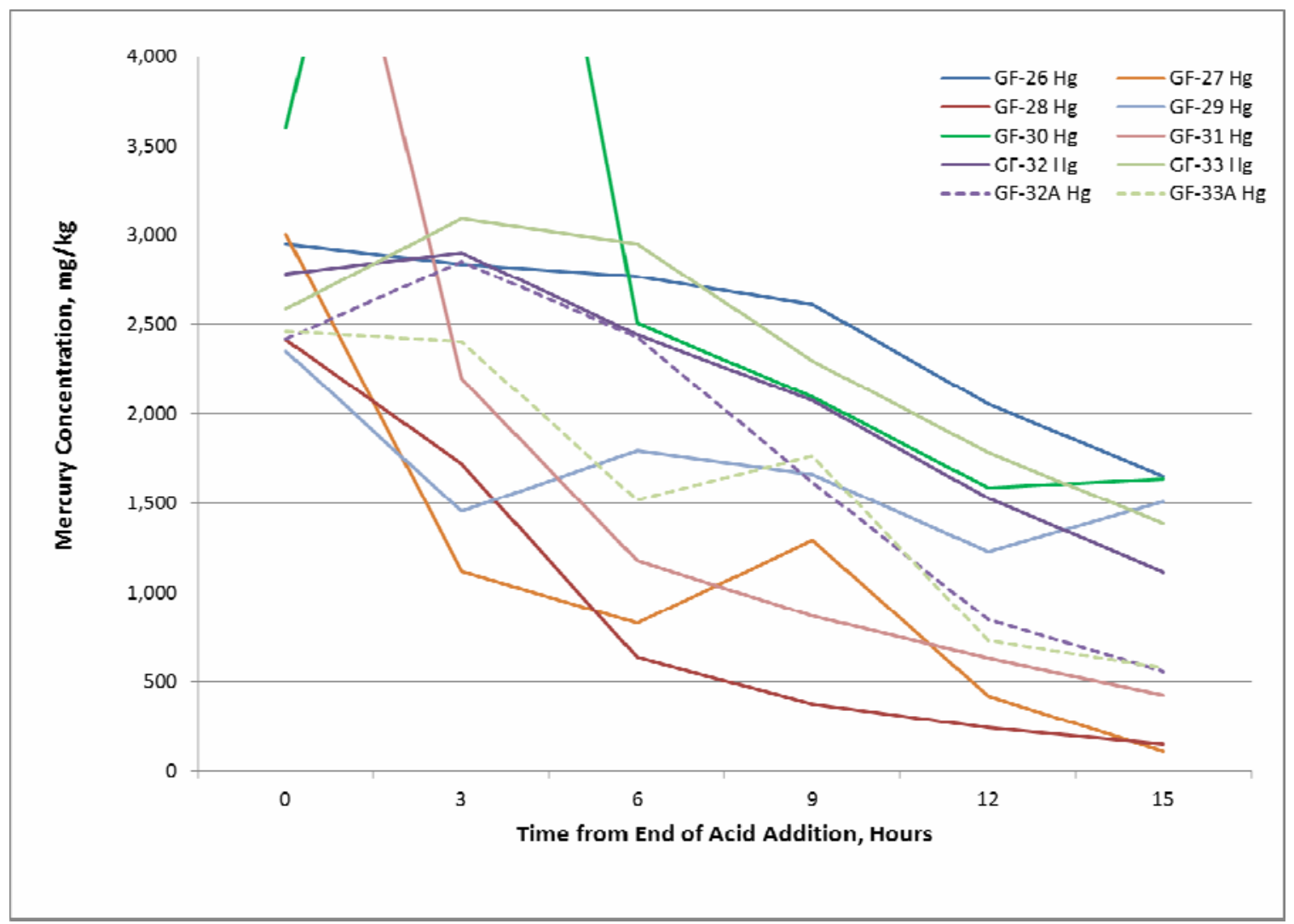

Figure 3-5. Mercury concentration with time in all SRAT cycles

In most cases except the HiFeLoMn (Runs GF27-28), the measured mercury concentration in the $150 \%$ acid stoichiometry run (GF27,29,31,33,33A) was equal or lower than the $100 \%$ acid stoichiometry run (GF26,28,30,32,32A) with the same sludge. This is summarized in the four graphs below, Figures 3-6 to 3-9. 
SRNL-STI-2011-00275

Revision 0

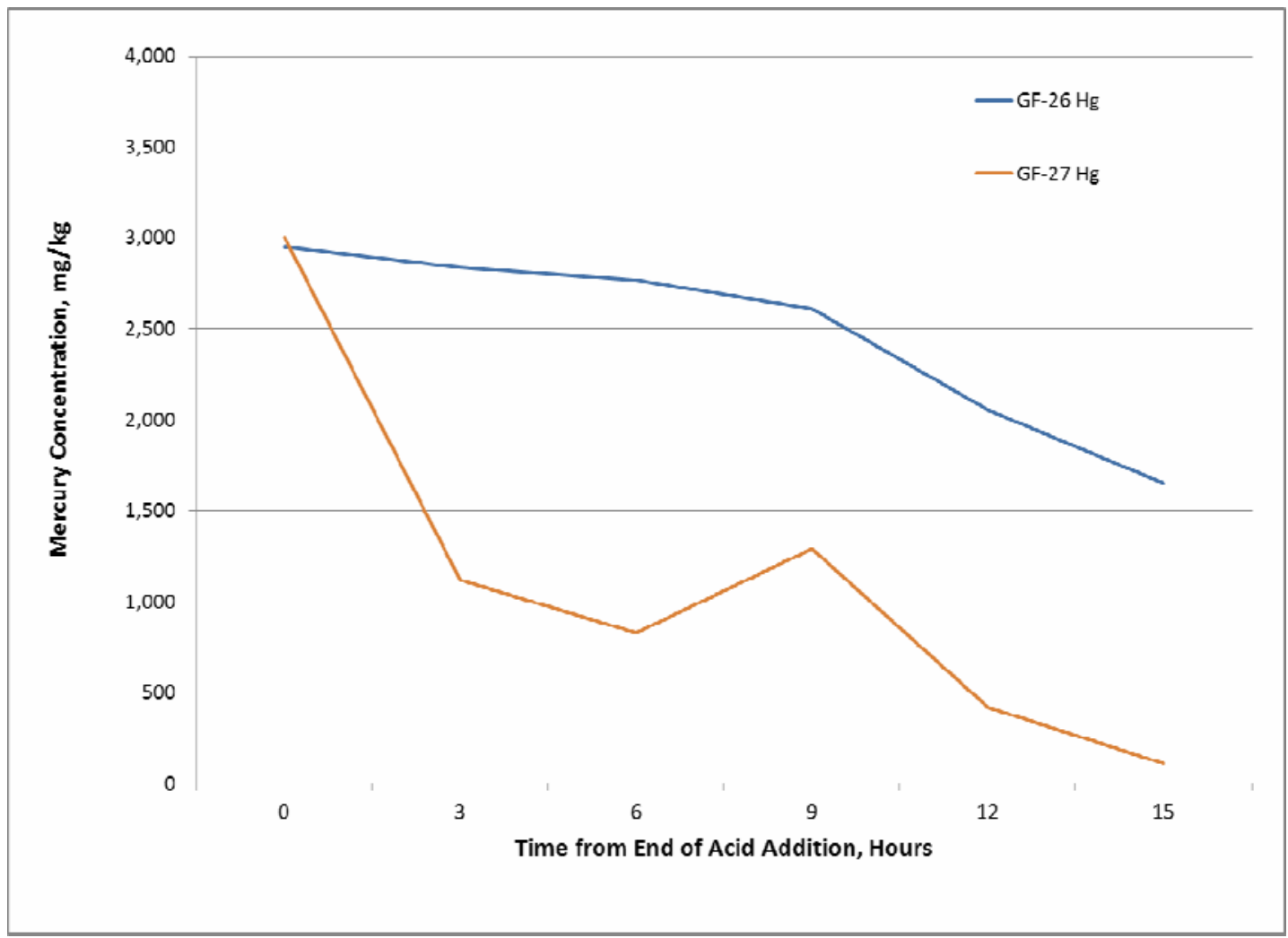

Figure 3-6. Mercury concentration with time in GF26 and GF27 SRAT cycles

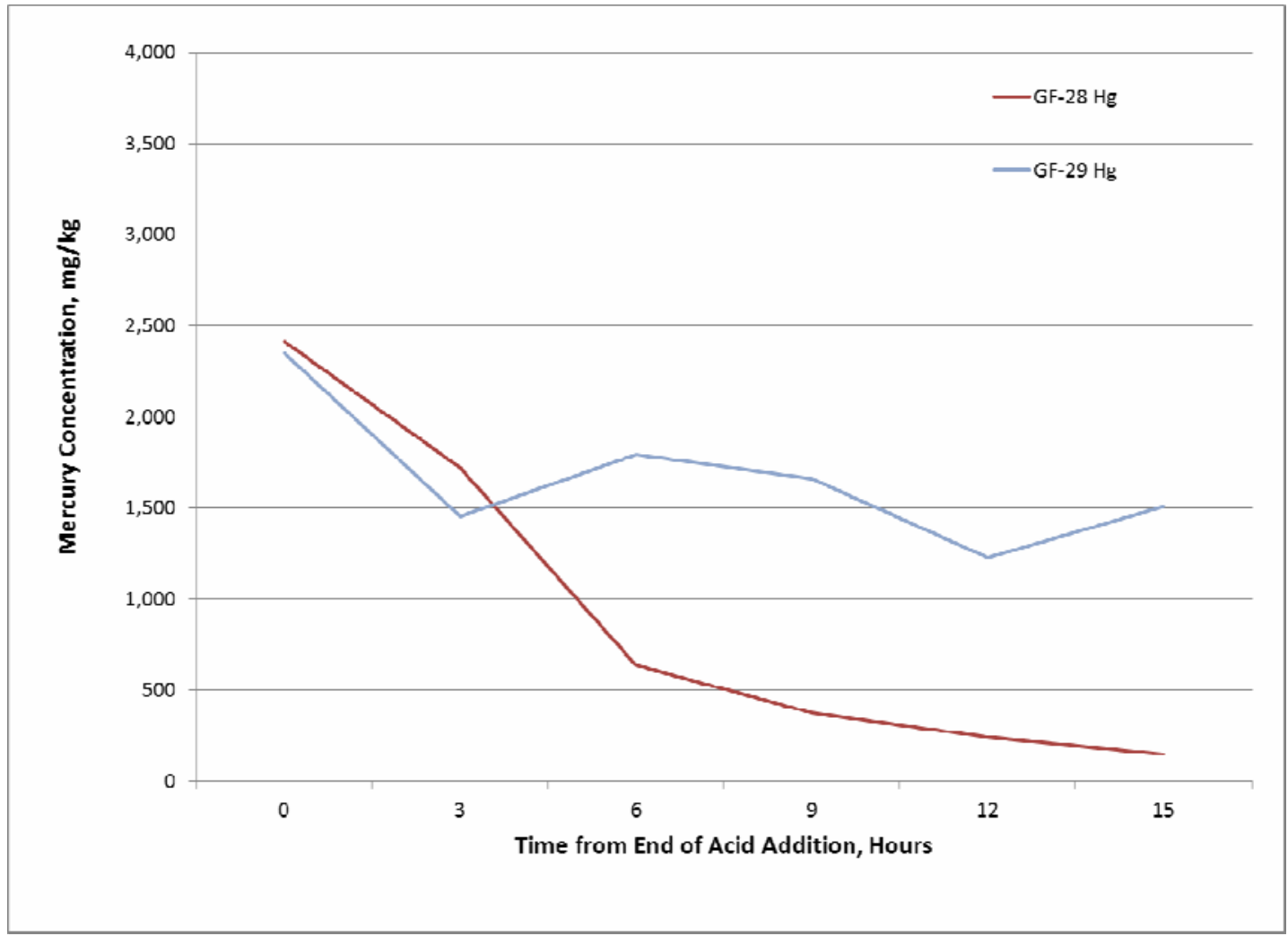

Figure 3-7. Mercury concentration with time in GF28 and GF29 SRAT cycles 
SRNL-STI-2011-00275

Revision 0

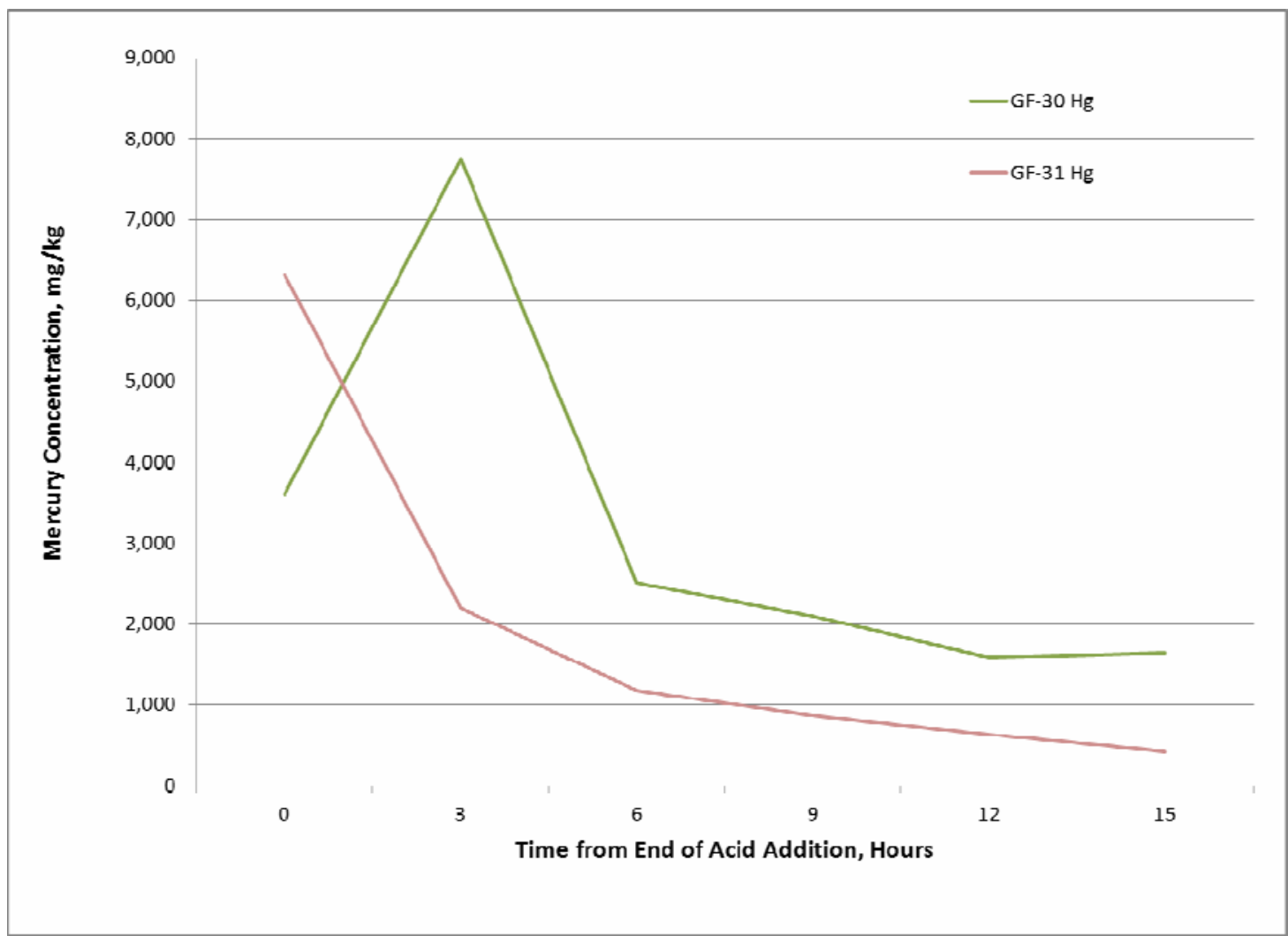

Figure 3-8. Mercury concentration with time in GF30 and GF31 SRAT cycles

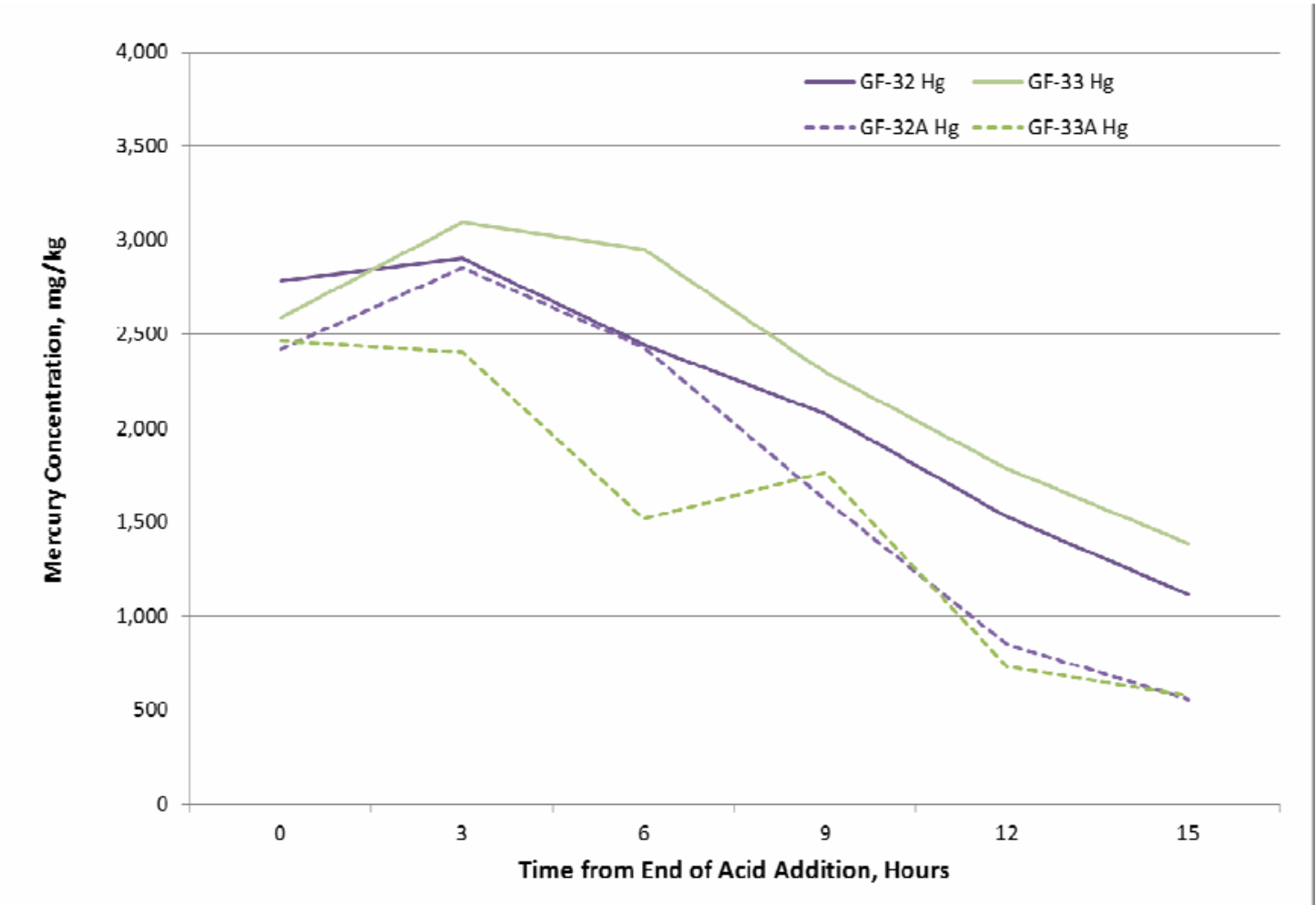

Figure 3-9. Mercury concentration with time in GF32, GF32A, GF33 and GF33A SRAT cycles 
Table 3-7 below shows the SRAT product mercury results for all of the runs in this series and the mercury recovered in the MWWT from each run. The mercury recovery was highest in the runs with high aluminum (low iron) and high manganese (Hi Mn, etc.). The mercury recovery was lowest in the high iron, low manganese run.

Table 3-7. SRAT Product Mercury Results

\begin{tabular}{|c|c|c|c|c|c|}
\hline $\begin{array}{c}\mathbf{1 0 0} \% \\
\text { Run }\end{array}$ & $\begin{array}{c}\text { SRAT Product } \\
\text { Hg } \\
\text { (wt\% TS) }\end{array}$ & $\begin{array}{c}\text { MWWT Hg } \\
\text { Recovered } \\
\text { /Hg Added (g) }\end{array}$ & $\begin{array}{c}\mathbf{1 5 0 \%} \\
\text { Run }\end{array}$ & $\begin{array}{c}\text { SRAT } \\
\text { Product Hg } \\
\text { (wt\% TS) }\end{array}$ & $\begin{array}{c}\text { MWWT Hg } \\
\text { Recovered } \\
\text { /Hg Added (g) }\end{array}$ \\
\hline \hline GF-26 & $0.57 \%$ & $2.5 / 10.2$ & GF-27 & $0.04 \%$ & $0.05 / 10.2$ \\
\hline GF-28 & $0.05 \%$ & $2.1 / 10.2$ & GF-29 & $0.54 \%$ & $2.9 / 10.2$ \\
\hline GF-30 & $0.56 \%$ & $5.4 / 10.2$ & GF-31 & $0.15 \%$ & $3.0 / 10.2$ \\
\hline \hline GF-32 & $0.51 \%$ & $4.0 / 10.2$ & GF-33 & $0.60 \%$ & $4.2 / 10.2$ \\
\hline GF-32A & $0.19 \%$ & $5.0 / 7.3$ & GF-33A & $0.19 \%$ & $4.7 / 7.3$ \\
\hline
\end{tabular}

All of the mercury removed and collected during these runs was retained for potential future analysis.

\subsection{SRAT REDOX}

Frit 418 was added to each crucible containing SRAT product samples to produce $36 \%$ waste loading. The crucibles were dried to a peanut butter consistency and were vitrified in nepheline sealed crucibles. The resulting glasses measured for REDOX $\left(\mathrm{Fe}^{2+} / \Sigma \mathrm{Fe}\right)^{17}$. The REDOX target for all the simulations in this study was 0.1. The target is achieved by predicting the SME product anion concentrations and adjusting the split of acids between nitric and glycolic/formic. Therefore the ability to hit a REDOX target is highly dependent on being able to accurately predict anion behavior in the SRAT cycle. Inserting the SRAT product data into the latest REDOX correlation gives a "predicted" REDOX that is different than the targeted REDOX of 0.1 .

The REDOX prediction equation used in this study with an added term for glycolate is ${ }^{18}$ :

$$
\begin{array}{ll}
\mathrm{Fe}^{2+} / \Sigma \mathrm{Fe}=0.2358+0.1999 *\left(2[\mathrm{~F}]+4[\mathrm{C}]+6[\mathrm{G}]+4\left[\mathrm{O}_{\mathrm{T}}\right]+5[\mathrm{~N}]-5[\mathrm{Mn}]\right) 45 / \mathrm{T} \\
\text { Where } \\
{[\mathrm{F}]=\text { formate }(\mathrm{mol} / \mathrm{kg} \mathrm{feed})} \\
{[\mathrm{C}]=\text { coal }(\text { carbon })(\mathrm{mol} / \mathrm{kg} \text { feed })} \\
{\left[\mathrm{O}_{\mathrm{T}}\right]=\text { oxalate }} \\
{[\mathrm{G}]=\text { glycolate }(\text { soluble and insoluble })(\mathrm{mol} / \mathrm{kg} \text { feed })} \\
{[\mathrm{Ng}]=\text { nitrate }+ \text { nitrite }(\mathrm{mol} / \mathrm{kg} \text { feed })} \\
{[\mathrm{Mn}]=\text { manganese }(\mathrm{mol} / \mathrm{kg} \text { feed })}
\end{array}
$$

Values less than zero or greater than one can be calculated with the REDOX equation, because it is a linear regression equation fit to experimental data. Values outside the range of zero to one, however, are physically impossible. A number less than zero can be interpreted as fully oxidized and likewise a number greater than one as fully reduced.

The predicted REDOX and the measured REDOX agreed reasonably well for all runs except GF32A and GF33A (LoFeHiMn). Most of the samples had a measured REDOX of 0 . The only samples that had REDOX values significantly above 0 were runs GF32A (0.29) and GF33A 
(0.22). Table 3-8 below shows the appropriate SRAT product data with the corresponding predicted REDOX values as well as the REDOX as measured.

Table 3-8. SRAT product data for REDOX calculations

\begin{tabular}{|l|c|c|c|c|c|c|c|c|c|}
\hline \multicolumn{1}{|c|}{ anions (mg/kg) } & GF26 & GF27 & GF28 & GF29 & GF30 & GF31 & GF32A & GF33A \\
\hline \hline nitrite & $<100$ & $<100$ & $<100$ & $<100$ & $<100$ & $<100$ & $<100$ & $<100$ \\
\hline nitrate & 62,350 & 81,400 & 55,700 & 79,300 & 59,450 & 83,050 & 56,800 & 78,050 \\
\hline \hline glycolate & 27,900 & 52,400 & 35,350 & 57,600 & 38,800 & 67,700 & 46,700 & 51,950 \\
\hline oxalate & $<100$ & 1,760 & 280 & 2,090 & $<100$ & 663 & 209 & 757 \\
\hline \hline formate & 3,085 & 4,205 & 5,010 & 6,600 & 2,765 & 6,060 & $<100$ & $<100$ \\
\hline \multicolumn{1}{|c|}{ Other properties } & & & & & & & & \\
\hline Mn (gmol/kg slurry) & 0.62 & 0.62 & 3.75 & 4.01 & 0.58 & 0.57 & 2.97 & 2.98 \\
\hline wt\% total solids & 29.10 & 28.14 & 30.19 & 27.79 & 29.26 & 28.55 & 29.75 & 29.66 \\
\hline \hline predicted REDOX & -0.17 & -0.10 & -0.06 & -0.07 & -0.01 & 0.10 & 0.05 & -0.15 \\
\hline \hline measured REDOX & 0.00 & 0.00 & 0.04 & 0.02 & 0.00 & 0.00 & 0.29 & 0.22 \\
\hline \begin{tabular}{l|l|l|l|l|l|} 
stoichiometry \\
(\% Koopman minimum)
\end{tabular} & 100 & 150 & 100 & 150 & 100 & 150 & 100 & 150 \\
\hline
\end{tabular}

\subsection{SRAT Rheology}

The Hi Fe-Hi Mn case had the highest wt \% insoluble solids, but it had the least viscous behavior. The two low iron cases had higher yield stresses than the two high iron cases, which is consistent with historical data indicating that HM sludges are more viscous than Purex sludges. The Lo FeHi Mn case was the least like the other three. It had nearly an order of magnitude higher yield stress for both the up and down curve fits in spite of having the lowest wt $\%$ insoluble solids. The Lo Fe-Lo Mn case may have received a little more acid in a relative sense (based on nitrite destruction results) which should have helped to thin it out some relative to the others, but it was the second most viscous of the four products. Table 3-9 shows the appropriate SRAT product rheology data. 
Table 3-9. SRAT product Bingham plastic model results

\begin{tabular}{|l|c|c|c|c|c|}
\hline & $\begin{array}{c}\text { Insoluble } \\
\text { Solids, wt \% }\end{array}$ & \multicolumn{2}{|c|}{$\begin{array}{c}\text { Up } \\
\text { Yield Stress, Pa }\end{array}$} & \multicolumn{2}{c|}{$\begin{array}{c}\text { Down } \\
\text { Consistency, cP }\end{array}$} \\
\hline Hi Fe-Hi Mn Sludge & 16.4 & 2.4 & 2.3 & 7.6 & 6.1 \\
\hline Hi Fe-Hi Mn 100\% SRAT Product & 18.0 & 3.3 & 1.8 & 7.0 & 9.8 \\
\hline Hi Fe-Hi Mn 150\% SRAT Product & 15.6 & 0.8 & 0.7 & 6.9 & 7.1 \\
\hline Hi Fe-Lo Mn Sludge & 15.1 & 5.5 & 3.7 & 4.7 & 7.1 \\
\hline Hi Fe-Lo Mn 100\% SRAT Product & 16.9 & 3.1 & 3.1 & 8.0 & 8.1 \\
\hline Hi Fe-Lo Mn 150\% SRAT Product & 15.4 & 0.6 & 0.5 & 5.3 & 5.9 \\
\hline Lo Fe-Hi Mn Sludge & 13.1 & 34 & 42 & 13.4 & 0.34 \\
\hline Lo Fe-Hi Mn 100\% SRAT Product & 16.8 & 24.2 & 24.7 & 14.2 & 13.5 \\
\hline Lo Fe-Hi Mn 150\% SRAT Product & 15.1 & 28.5 & 29.5 & 15.7 & 14.0 \\
\hline Lo Fe-Lo Mn Sludge & 15.0 & 6.4 & 5.2 & 6.4 & 8.4 \\
\hline Lo Fe-Lo Mn 100\% SRAT Product & 16.3 & 40.9 & 31.3 & 6.1 & 21.6 \\
\hline Lo Fe-Lo Mn 150\% SRAT Product & 14.7 & 0.4 & 0.3 & 4.6 & 4.8 \\
\hline
\end{tabular}

Once the $\mathrm{pH}$ of slurry dropped below 6 , the slurry thinned considerably. The glycolic-formic flowsheet $\mathrm{pH}$ did not change appreciably after acid addition during SRAT processing. The HiFe SRAT products had low yield stress values. These properties constitute a relatively low viscosity SRAT product. The LoFe SRAT products had high yield stress values at $100 \%$ acid stoichiometry and low yield stress values at $150 \%$ acid stoichiometry. Flow curves for the SRAT products were obtained by using a Haake RS600 rheometer and the current DWPF simulant rheology protocol ${ }^{19}$. The up and down curves were fit to a Bingham plastic model to determine yield stress and consistency. Down flow curve data are the generally preferred choice for comparisons between systems. The flow curves are included in Appendix A.2.

\subsection{SRAT Foaming Issues}

The runs were completed with Antifoam 747 (Siovation Lot 101876-1111). This was the most recent antifoam lot available. Foaming was noted in three of the four HiFe runs (GF27, GF28, and GF29). An additional $100 \mathrm{ppm}$ antifoam addition was required in both HiFe, high acid stoichiometry runs, during nitric acid addition. No additional antifoam was added in the LoFe runs. No foaming was noted in the LoFe runs although the slurry was very thick and did entrain air and process gases. The typical SRAT antifoam strategy (200 ppm prior to nitric addition, 100 ppm prior to formic acid addition, and $500 \mathrm{ppm}$ prior to boiling) was acceptable in this testing with the exception of the antifoam additions noted above. 


\subsection{Conclusions}

Testing was completed to demonstrate the viability of the newly developed glycolic acid/formic acid flowsheet on processing in the Defense Waste Processing Facility's (DWPF) Chemical Process Cell (CPC). The Savannah River National Laboratory (SRNL) initiated a sludge matrix study to evaluate the impact of changing insoluble solid composition on the processing characteristics of slurries in DWPF. Four sludge simulants were prepared to cover two compositional ranges in the waste. The first was high iron/low aluminum versus low iron/high aluminum (referred to as $\mathrm{HiFe}$ or $\mathrm{LoFe}$ in this report). The second was high calciummanganese/low nickel, chromium, and magnesium versus low calcium-manganese/high nickel, chromium, and magnesium (referred to as HiMn or LoMn in this report). These two options can be combined to form four distinct sludge compositions.

The sludge matrix study called for testing each of these four simulants near the minimum acid required for nitrite destruction (100\% acid stoichiometry) and at a second acid level that produced significant hydrogen by noble metal catalyzed decomposition of formic acid $(150 \%$ acid stoichiometry). Four simulants were prepared based on the four possible combinations of the $\mathrm{Al} / \mathrm{Fe}$ and $\mathrm{Mn}-\mathrm{Ca} / \mathrm{Mg}-\mathrm{Ni}-\mathrm{Cr}$ options. Preliminary simulant preparation work has already been documented. ${ }^{20}$ The four simulants were used for high and low acid testing.

Eight planned experiments (GF26 to GF33) were completed to demonstrate the viability of the glycolic-formic flowsheet. Composition and physical property measurements were made on the SRAT product. Composition measurements were made on the condensate from the Mercury Water Wash Tank (MWWT), Formic Acid Vent Condenser (FAVC), ammonia scrubber and on SRAT samples pulled throughout the SRAT cycle. Updated values for formate loss and nitrite-tonitrate conversion were found that can be used in the acid calculations for future sludge matrix process simulations with the glycolic acid/formic acid flowsheet.

Preliminary results of the initial testing indicate:

- Hydrogen generation rate was very low throughout all SRAT cycles.

- The mercury concentration of the SRAT product was below the $0.8 \mathrm{wt} \%$ limit in all runs.

- Nitrite in the SRAT product was $<100 \mathrm{mg} / \mathrm{kg}$ for all runs

- Foaminess was not an issue using the nominal antifoam addition strategy in these tests.

- The high aluminum sludges (LoFe, HM type sludges) were much more viscous than the Hi Fe sludges. At 100\% acid stoichiometry, the SRAT products from the high aluminum sludges were very viscous but at $150 \%$ acid stoichiometry, the SRAT products from the high aluminum sludges were very thin. This makes the glycolic acid/formic acid flowsheet an improvement for processing more viscous sludges. However, there may be a tradeoff between dissolution of metals and rheology.

- The $\mathrm{pH}$ of the SRAT products was from $2.7-3.1$ for the $150 \%$ acid stoichiometry runs and 5.1-6.1 for the $100 \%$ acid stoichiometry runs, significantly lower than is typical of the baseline nitric acid/formic acid flowsheet. 


\subsection{Recommendations}

The glycolic/formic flowsheet is recommended as a viable flowsheet alternative to the baseline DWPF flowsheet. In the testing that has been performed to date, this flowsheet meets or outperforms the current flowsheet in minimizing off-gas generation, mercury removal, thinner product rheology and having a wide processing window regarding both the glycolic-formic ratio and acid stoichiometry. The addition of glycolic acid leads to SRAT products that are rheologically much thinner which means that more concentrated products can be produced, leading to potentially larger batches and higher throughput.

The glycolic-formic flowsheet should be demonstrated with actual waste in SRNL Shielded Cells SRAT and SME processing, including the production of glass and measurement of the glass REDOX.

The glycolic-formic flowsheet has not been tested at acid stoichiometries of less than $100 \%$. Demonstration of this flowsheet at an acid stoichiometry of $<100 \%$ is recommended and might be useful for high iron sludge processing. 
SRNL-STI-2011-00275

Revision 0

\subsection{References}

1 Holtzscheiter, E. W. Technical Task Request - Perform Glycolic-Formic Acid Flowsheet Development, Definition, and Demonstration, HLW-DWPF-TTR-2010-0003, Revision 1, Savannah River

Remediation, Aiken, SC, September 2010.

2 Pickenheim, B.R., M.E. Stone, SRAT Alternative Reductant Feasibility Assessment - Phase I, SRNLSTI-2009-00120, Savannah River National Laboratory, Aiken, SC, February 2009.

3 Pickenheim, B.R., M.E. Stone, D.K. Peeler, Selection and Preliminary Evaluation of Alternative Reductants for SRAT Processing, SRNL-STI-2009-00120, Savannah River National Laboratory, Aiken, SC, June 2009.

4 Pickenheim, B.R., M.E. Stone, J.D. Newell, Glycolic-Formic Acid Flowsheet Development, SRNLSTI- 2010-00523, Rev 0, Savannah River National Laboratory, Aiken, SC, November 2010.

5 D.P. Lambert, B.R. Pickenheim, M.E. Stone, J.D. Newell, D.R. Best, Glycolic - Formic Acid Flowsheet Final Report for Downselection Decision, SRNL-STI- 2010-00523, Rev 1, Savannah River National Laboratory, Aiken, SC, March 2011

6 D. C. Koopman, D. R. Best, Sludge Batch 6 Phase II Flowsheet Simulations, SRNL-STI-2010-00041, Savannah River National Laboratory, Aiken, SC, March 2010.

7 Pickenheim, B.R., Choi, A.S., Task Technical and Quality Assurance Plan for Glycolic-Formic Acid Flowsheet Development, Definition and Demonstration Tasks 4-7A, SRNL-RP-2009-00484, Revision 2, Savannah River National Laboratory, Aiken, SC, October 2010.

8 Koopman, D. C., Statistical Evaluation of Processing Data from the Rh-Ru-Hg Matrix Study, SRNLSTI-2009-00084, SRNL, Aiken, SC, 29808 (April 2009).

9 D. C. Koopman, D. P. Lambert, Initial Characterizations and SRAT Simulations of Four Sludge Matrix Study Simulants, SRNL-STI-2009-00606, REVISION 0, Savannah River National Laboratory, Aiken, SC, December 2009.

10 Koopman, D.C., A.I. Fernandez and B.R. Pickenheim, Preliminary Evaluations of Two Proposed Stoichiometric Acid Equations, SRNL-L3100-2009-00146, Savannah River National Laboratory, Aiken, SC, 2009.

11 Stone, M. E., Lab-Scale CPC Equipment Set-up, SRNL-ITS-2006-00074, Savannah River Site, Aiken, SC 29808 (2008).

12 Manual L29, Procedure ITS-0094, Rev. 3, Laboratory Scale Chemical Process Cell Simulations, Savannah River Site, Aiken, SC 29808 (2006)

13 Glycolic-Formic Flowsheet Development, Part I, WSRC-NB-2011-00021, .

14 Glycolic-Formic Flowsheet Development, Part II, WSRC-NB-2011-00022.

15 Koopman, D.C., A.I. Fernandez, B.R. Pickenheim, Preliminary Evaluations of Two Proposed Stoichiometric Acid Equations, Revision 0, Savannah River Site, Aiken, SC 29808 (2009).

16 Jantzen, C.M. and M.E. Stone, Role of Manganese Reduction/Oxidation (REDOX) on Foaming and Melt Rate in High Level Waste Melters, WSRC-STI-2006-00066, Savannah River Site, Aiken, SC, March 2007.

17 Manual L29, Procedure ITS-0052, Rev. 2, Heat Treatment of Waste Slurries for REDOX $\left(\mathrm{Fe}^{2+} / \sum \mathrm{Fe}\right)$ and Chemical Composition Measurement.

18 Jantzen, C. M. and M. E. Stone, Role of Manganese Reduction/Oxidation (REDOX) on Foaming and Melt Rate in High Level Waste Melters, WSRC-STI-2006-00066, Savannah River Site, Aiken, SC, 29808 , March 2007.

${ }^{19}$ Koopman, D. C., Rheology Protocols for DWPF Samples, WSRC-RP-2004-00470, Savannah River Site, Aiken, SC, 29808 (October 2004).

20 Holtzscheiter, E. W. Technical Task Request - Perform Glycolic-Formic Acid Flowsheet Development, Definition, and Demonstration, HLW-DWPF-TTR-2010-0003, Revision 1, Savannah River Remediation, Aiken, SC, September 2010. 
SRNL-STI-2011-00275

Revision 0

\subsection{Appendix A}

\section{A.1 Rheology Flow Curves}

A.2 Additional GC Data 


\section{A.1 Rheology Flow Curves}

HiFeLoMn Alternative Reductant SRAT Product Rheology

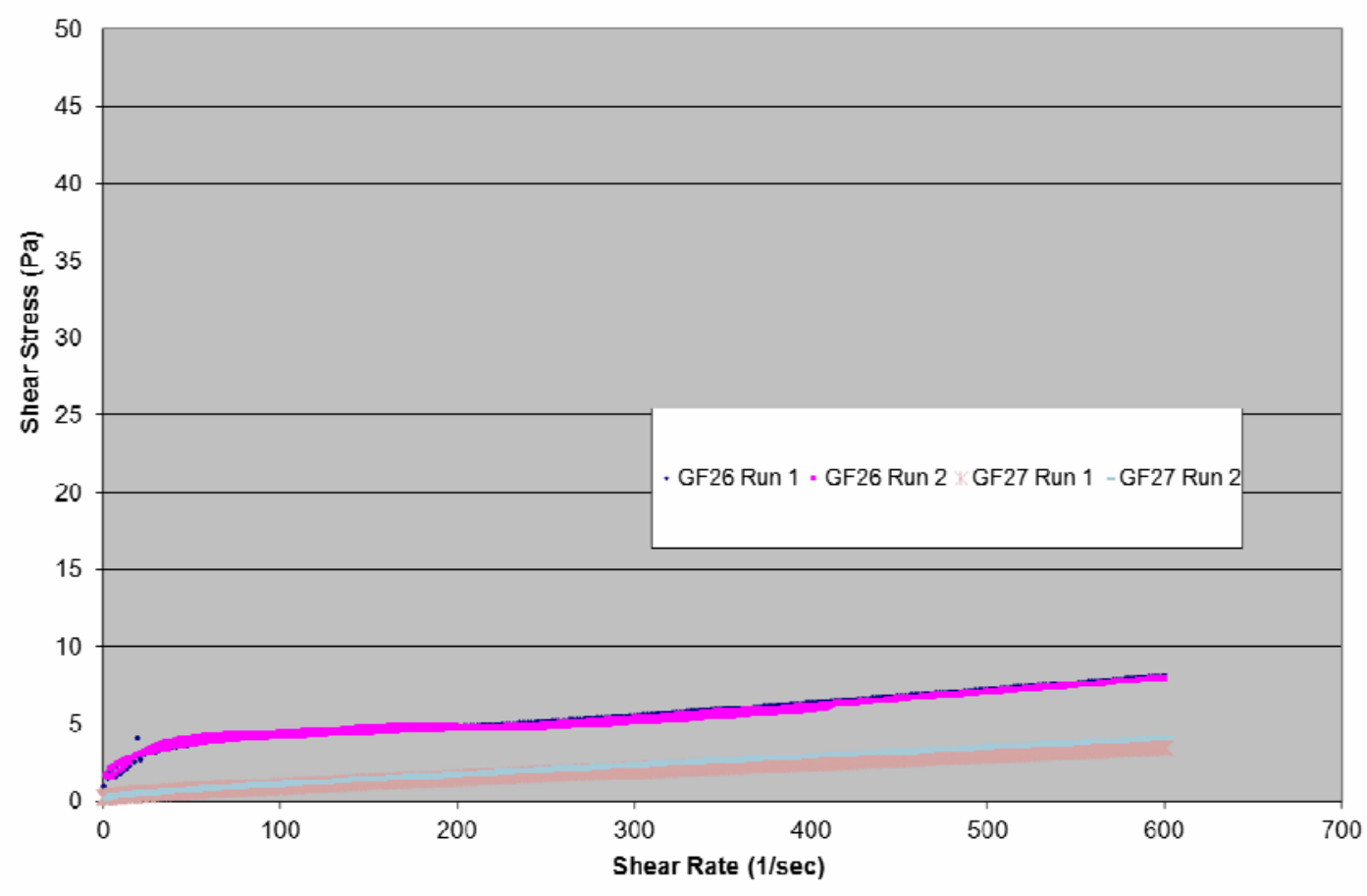

HiFeHiMn SRAT Product Rheology

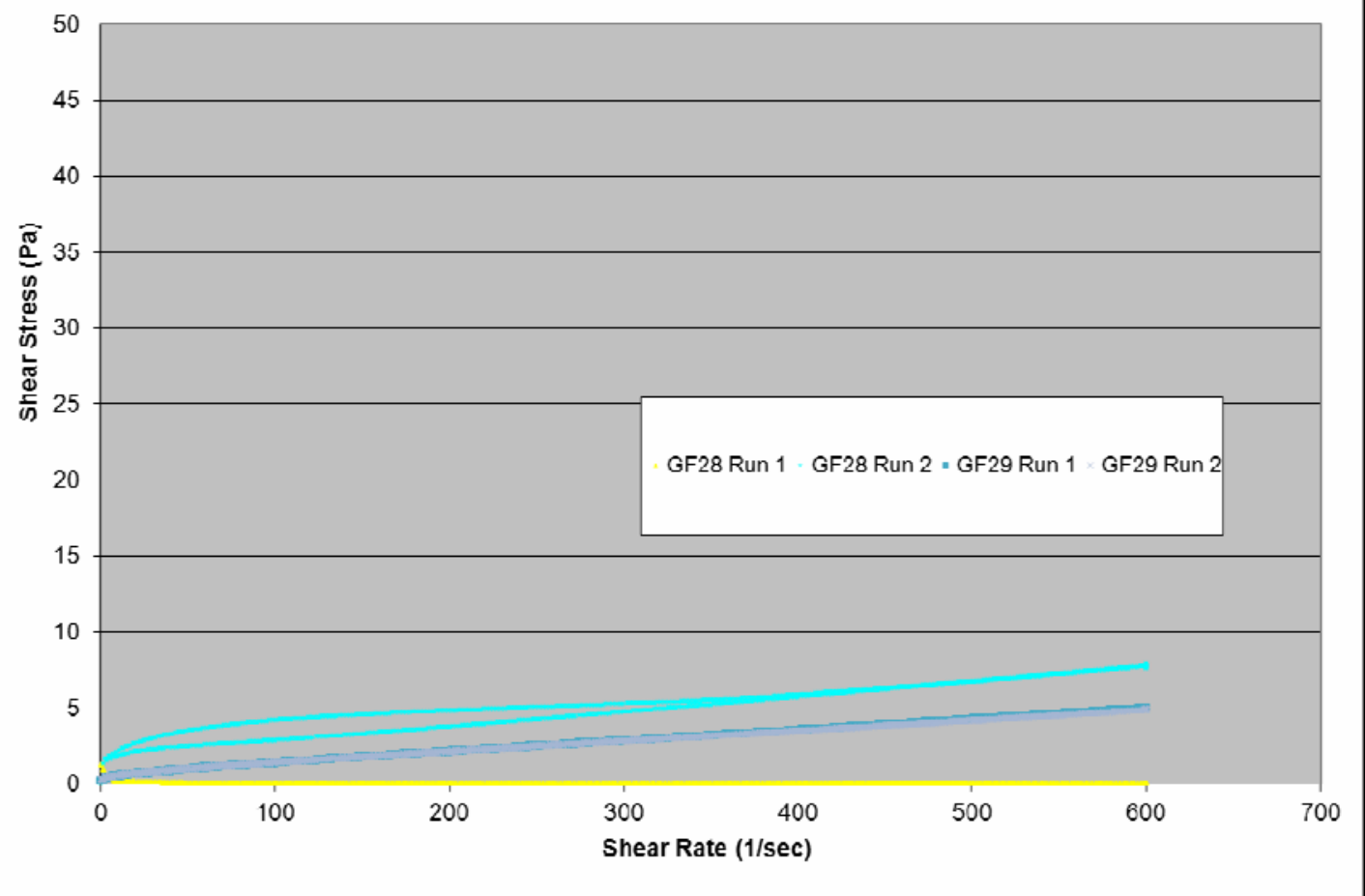




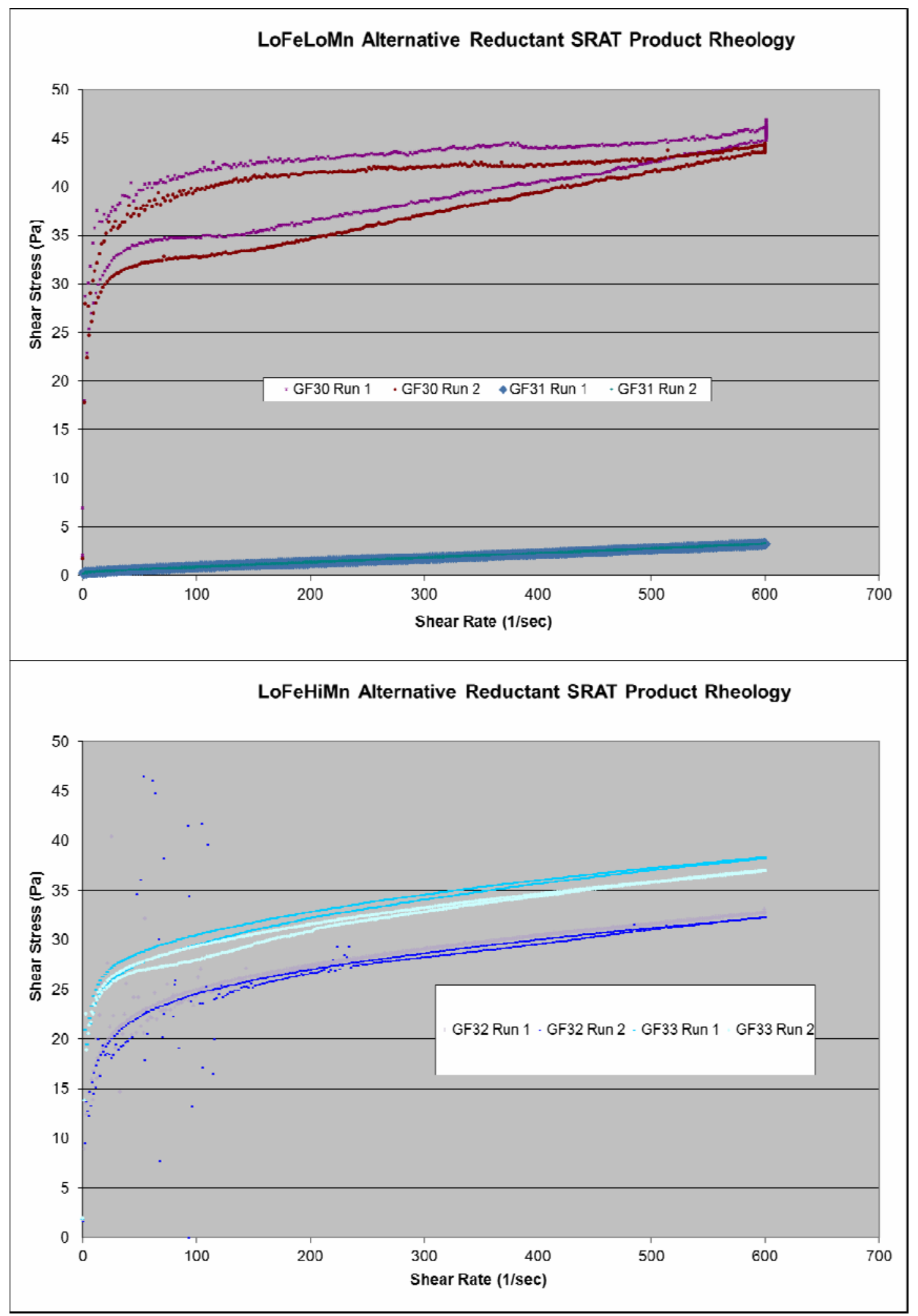


SRNL-STI-2011-00275

Revision 0

\section{A.2 Additional GC Data}

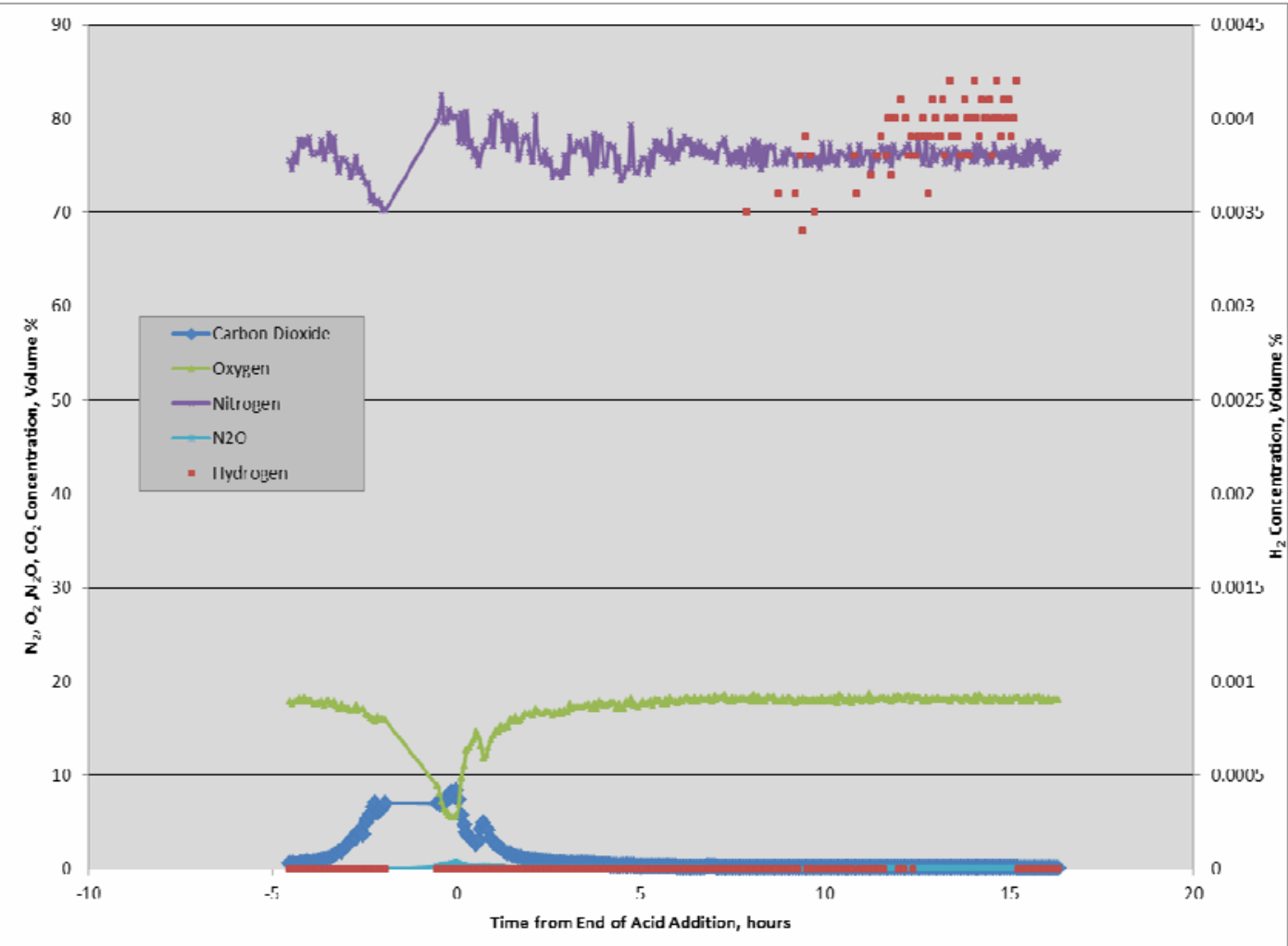

GF 26

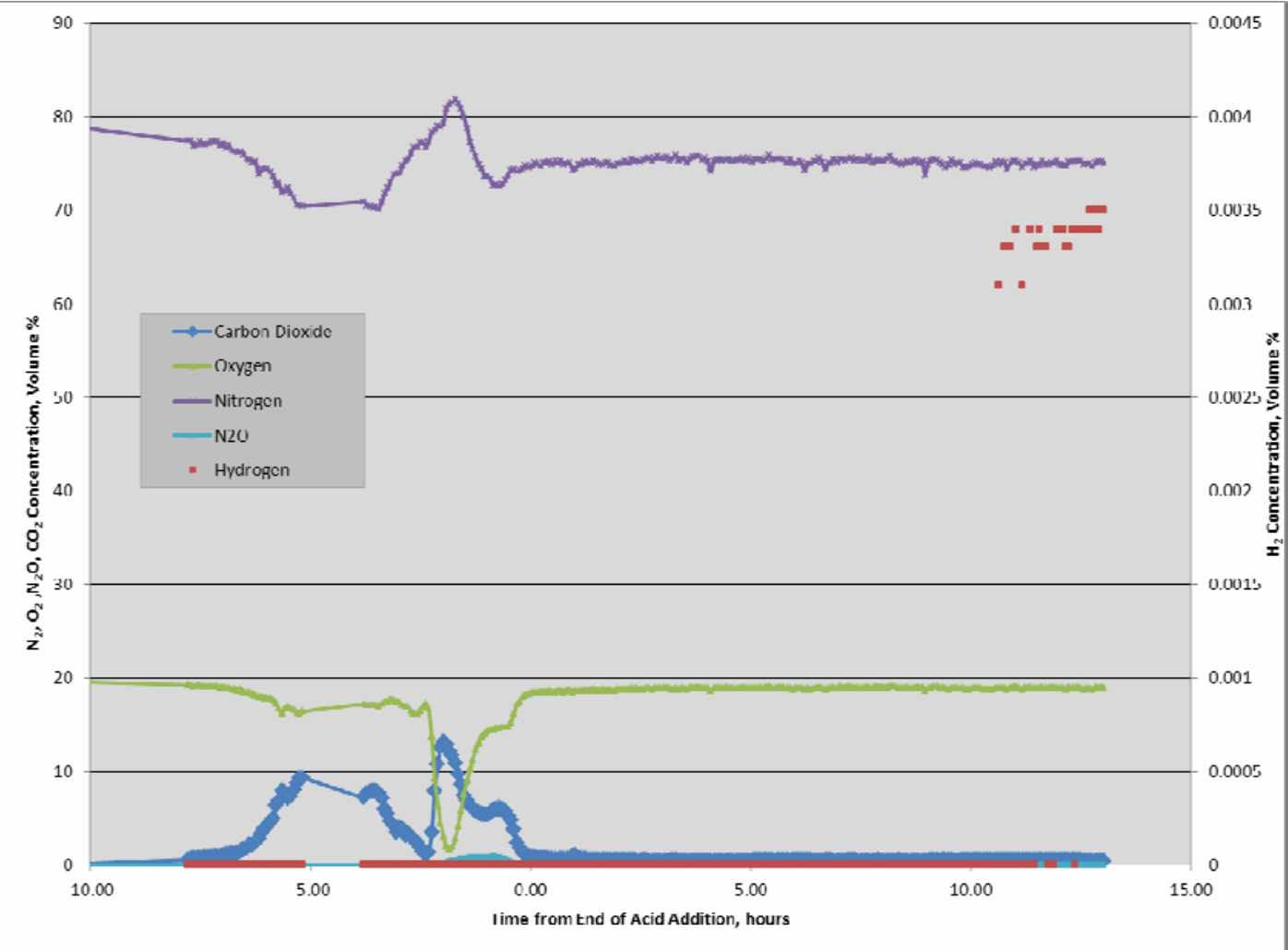

GF27 
SRNL-STI-2011-00275

Revision 0
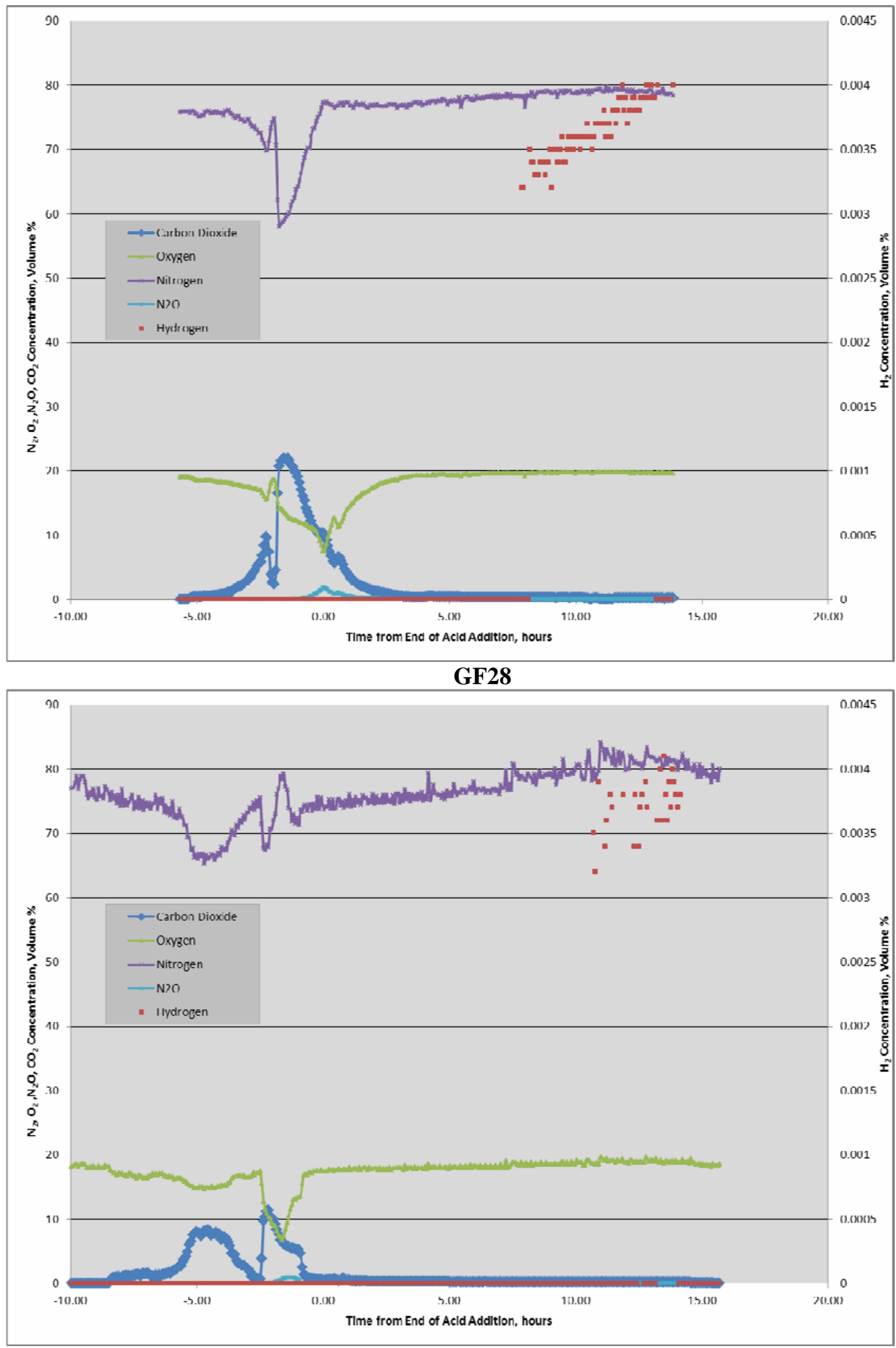

GF29 
SRNL-STI-2011-00275

Revision 0
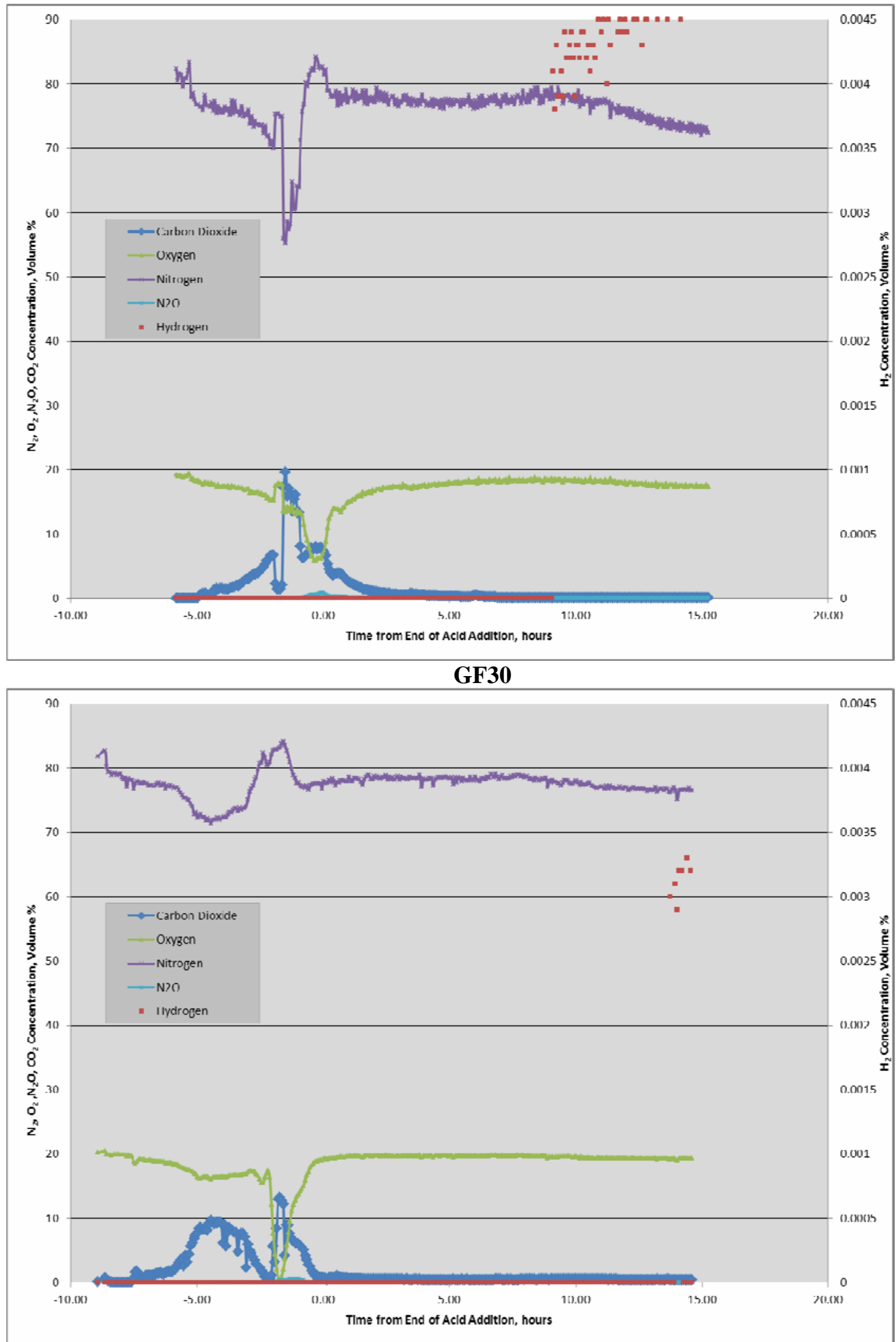

GF31 
SRNL-STI-2011-00275

Revision 0

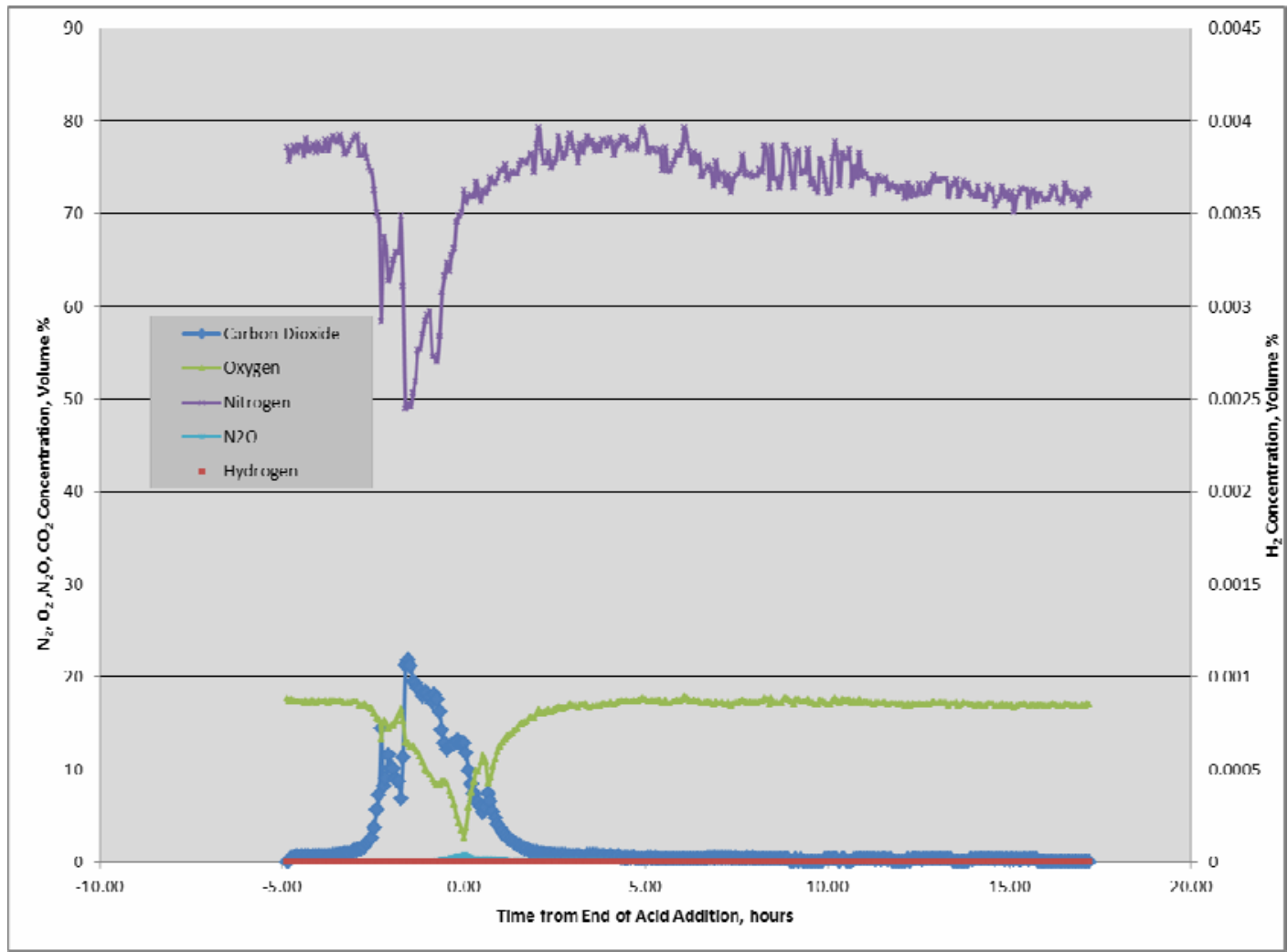

GF32A

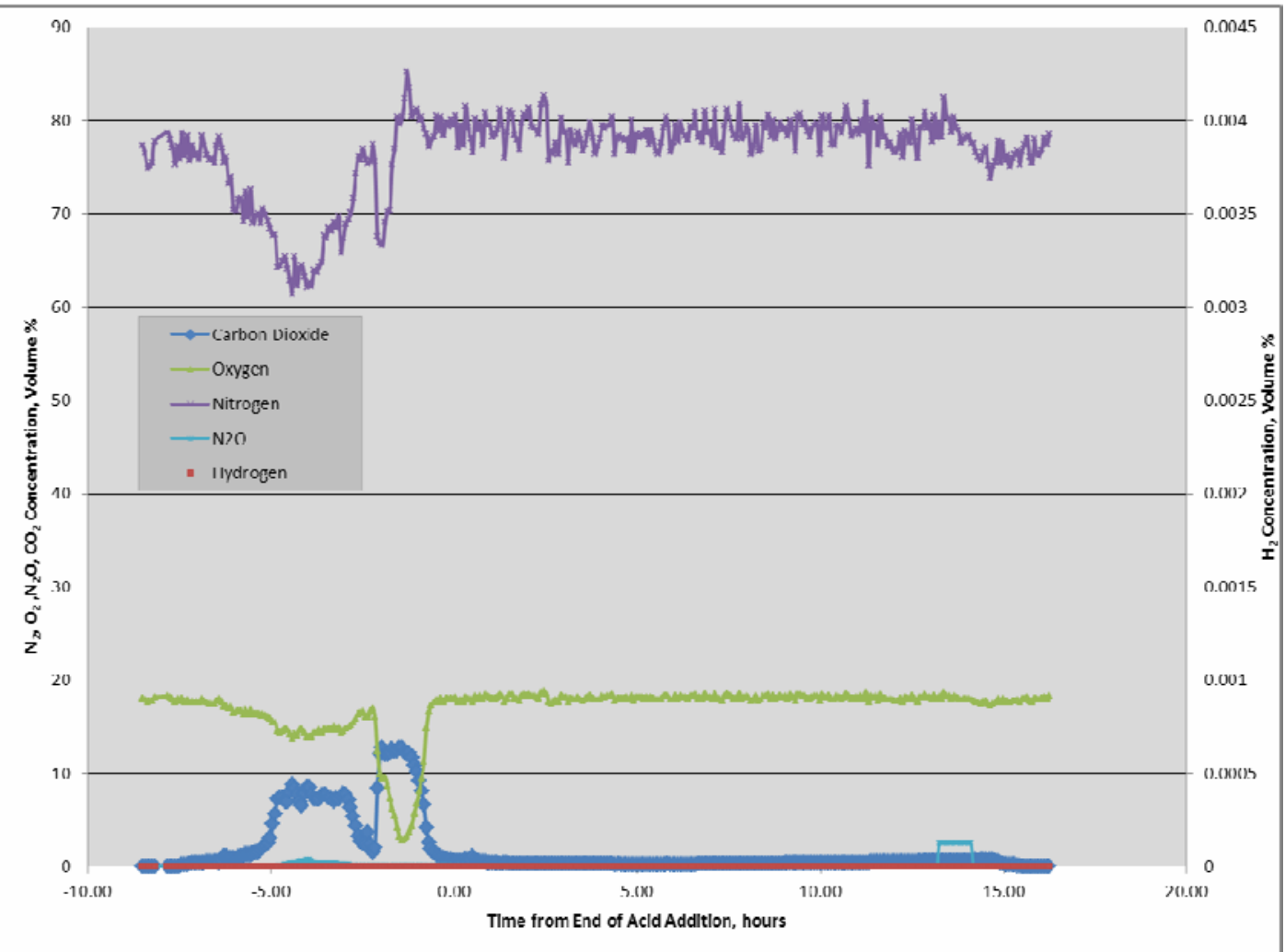

GF33A 

A. B. Barnes, 999-W
D. A. Crowley, 773-43A
S. D. Fink, 773-A
B. J. Giddings, 786-5A
C. C. Herman, 999-W
S. L. Marra, 773-A
F. M. Pennebaker, 773-42A
W. R. Wilmarth, 773-A
C. J. Bannochie, 773-42A
J. M. Gillam, 766-H
B. A. Hamm, 766-H
J. F. Iaukea, 704-30S
J. E. Occhipinti, 704-S
W. O Pepper, 704-S
D. K. Peeler, 999-W
J. W. Ray, 704-S
H. B. Shah, 766-H
D. C. Sherburne, 704-S
M. E. Stone, 999-W
B. R. Pickenheim, 704-28S
J. R. Zamecnik, 999-W
M. A. Broome, 704-29S
R. N. Hinds, 704-S
J. P. Vaughan, 773-41 A
J. M. Bricker, 704-27S
T. L. Fellinger, 704-26S
E. W. Holtzscheiter, 704-15S
A. V. Staub, 704-27S
K. R. Shah, 704-S
M. T. Keefer, 766-H
D. P. Lambert, 999-W
D. C. Koopman, 999-W
J. D. Newell, 999-W
D. R. Best, 999-W
R. E. Eibling, 999-W
W. T. Riley, 999-W
P. R. Jackson, 703-46A
D. W. McIlmoyle, 766-H 